Uşak Üniversitesi Sosyal Bilimler Dergisi

$2015,8 / 4$

\title{
6-7. Sınıf Sosyal Bilgiler Ders Kitaplarındaki Haritaların Kartografik Tasarımlarının Kazanımlar Açısından İncelenmesi
}

\author{
İlkay BUĞDAYCI \\ İbrahim Öztuğ BİLDİİCİ** \\ Bülent TARMAN***
}

\section{Öz}

$\mathrm{Bu}$ çalışmanın amacı, sosyal bilgiler ders kitaplarında yer alan haritaların kartografik tasarım kapsamında incelenerek beklenen kazanımlara etkisinin değerlendirilmesidir.

Günümüzde pek çok alanda (mühendislikten askerliğe, eğitim öğretimden bilimsel çalışmalara kadar) kullanılmakta olan haritaların, gelişmiş ülkelerde, eğitim sürecinin başlangıcında okul öncesine yönelik hazırlanmış resimli eğlenceli haritalardan oluşan atlaslar ve kitaplarla hayatın içinde yer aldığı görülmektedir. Yetişkinlerin bilinçli harita kullanıcısı olabilmeleri, çocuk haritaları ve eğitime yönelik tasarlanan haritaların erken yaşlardan itibaren etkin olarak kullanımı ile doğrudan ilişkilidir. Ayrıca haritaların etkin olarak kullanılabilmesi, haritanın amacına uygun olarak tasarlanmasına, kartografın tecrübesine ve haritanın kullanıcının seviyesine uygun olup olmamasına bağlıdır.

Ülkemizde eğitim alanında gerek ders kitaplarında gerekse atlaslarda kullanılan haritaların genel olarak amaca ve kullanıcıya uyumlu olarak tasarlandığı söylenemez. Eğitimi desteklemek, derslerin kazanımlarına katkı sağlamak amacıyla ders kitaplarına eklenen haritaların öncelikle kullanıcıların eğitim ve algılama seviyelerine uygun olarak tasarlanması gerekmektedir. Bu çalışmada ilk olarak kartografik tasarım yöntemleri kısaca açıklanmış ve bu yöntemler doğrultusunda 6. ve 7. sınıf sosyal bilgiler ders kitaplarında yer alan haritaların kartografik tasarım açısından incelemesi yapılmıştır. Bazı haritalarda ölçek, işaret tablosu gibi temel kavramların olmadığı, bazı haritalarda hatalı bilgilerin olduğu, tematik haritaların doğru yöntem ve tekniklerle tasarlanmadığı ve bu nedenle algılama hatalarına neden olduğu vb. sorunlar görülmüştür. Kartografik tasarım açısından incelendiğinde, eğitim alanında kullanılan

"Yrd. Doç. Dr., Necmettin Erbakan Üniversitesi, Harita Müh. Bölümü

** Prof. Dr., Selçuk Üniversitesi, Harita Mühendisliği Bölümü

*** Doç. Dr. Gazi Üniversitesi, Sosyal Bilgiler Eğitimi 
haritaların Milli Eğitim Bakanlığı (MEB) tarafından belirlenen kazanımları karşılayacak nitelikte olduğu söylenemez. Haritalar hangi alanda kullanılacaksa kullanılsın kartografik tasarım kurallarına uygun olarak tasarlanması gerekmektedir. Eğitimin ilk yıllarından başlanarak kurallara uygun olarak tasarlanmış nitelikli haritaların etkin olarak kullanımının sağlanmasıyla harita kullanma bilinci ve kültürü yerleşmiş olacaktır. Bu ülkemiz için önemli bir ihtiyaçtır.

Anahtar Kelimeler: Eğitimde Harita Kullanımı, Harita Tasarımı, Kartografik Tasarım.

\section{An Evaluation of Cartographic Design of Maps in 6-7th Class Social Studies Course Books in Terms of the Gains of the Courses}

\section{Abstract}

The aim of this study is to evaluate the effects of map to expected gains, by examining map within social study textbooks in terms of cartographic design.

In developed countries its seen that maps which being used in many themes (from engineering to military, education and training to scientific studies and etc.) took place in life with television programs, computer games, with fun and picture maps prepared for preschool in atlases and books at the beginning of the training process even at an early age. The children of today are society's future mapmakers and map users.

An important aim of the geography courses in the primary school curriculum of the Ministry of Education is to gain the ability of reading, analyzing, understanding maps. In order to contribute to the course of the gains and to support social science education, maps must be designed according to the users' level of education and perception. In this study, basic information about the design of general cartographic map design rules and the child is given. Located on the 6th and 7th grade social studies textbook maps were evaluated in this context. Available maps were also examined in terms of aimed acquisitions within the scope of Ministry of Education curriculum. Some maps designed without basic concepts such as scale or legend, some others have incorrect information. Thematic maps are not designed with the convenient methods and techniques and therefore have been shown to cause misunderstandings in the field of education. It can not be said that maps in the field of education, could satisfy gains which determined by the Ministry of Education.

Keywords: Map Use in Education, Map Design, Cartographic Design. 


\section{Sosyal Bilgiler Eğitiminde Haritanın Önemi}

İlköğretimde harita kullanımının gelişmesinde ve haritaların etkin olarak kullanılmasındaki en önemli faktörler, sosyal bilgiler ders müfredatı, mevcut haritaların niteliği, öğretmenlerin harita kullanımı konusunda yeterli bilgiye sahip olması ve bu konuda öğrenciyi teşvik etmesi olarak sıralanabilir. Eğitim müfredatında harita ile ilgili yer alan konular için sosyal bilgiler ve coğrafya alanında uzman kişilerin yanında harita bilgilerinin doğru ifade edilmesi açısından kartografların da konu ile ilgili deneyimlerinden ve bilgi birikimlerinden yararlanılması gerekmektedir. Eğitimde yer alan haritaların hangi yönlerden eksik olduğu, tasarım açısından nelere dikkat edilmesi gerektiği, harita kullanımının geliştirilmesi konusunda öğretmen ve ders müfredatı konusunda Milli Eğitim Bakanlığı'na da bir takım görevler düşmektedir.

Harita kullanımının yaygınlaştırılması, etkin olarak kullanımının sağlanması konusunda kartografların önemli görevleri vardır. Bugünün çocukları, harita kullanımı eğitimin ilk dönemlerinden itibaren başlatıldığında, ileriye dönük bilinçli harita kullanıcısı olabilecektir. Bunun gerçekleşmesi için kartografya ve sosyal bilgiler alanında uzman kişilerin ve öğretmenlerin bir araya gelerek, eğitimin her kademesinde nitelikli haritaların yer alması, harita bilgilerinin öğretilmesinin sağlanması için gerekli özveriyi göstermeleri gerekmektedir. Ülkemizde henüz sosyal bilgiler alanında uzman kişilerin ve kartografların bir araya gelerek ortak çalışma alanları oluşturmaması haritaların bilinçli ve etkin olarak kullanılamaması ve harita kültürünün oluşmaması konusundaki geri kalmışlığın temel nedenlerinden birisidir. Gelişmiş ülkelerde üniversitelerde sosyal bilimciler ve kartografların aynı birimlerde çalıştığı, harita üretimine ve kullanımına katkı sağladığı görülmektedir. Bu nedenle kartografların ve sosyal bilgiler alanında uzman kişilerin ortak çalışma alanları yaratmaları zorunlu hale gelmiştir.

Harita yapımında kullanılan işaretler, kartografın (ya da uzmanın) deneyimi, eğitimi ve yorumlama yeteneği gibi etkenlere doğrudan bağlıdır. Kullanıcının zihninde oluşan işaret ise zihinde meydana gelen çağrışımlar sonucu ortaya çıkar. Bu zihinsel süreç de harita kullanıcısının tecrübe, eğitim, yaş ve yorumlama yeteneği gibi etkenlere bağlıdır. Harita ve haritaya bağlı kartografik konumsal bilgi; verinin yararlı bilgiye dönüştürülmesinde önemli bir araçtır. Bu süreçte bilginin yararlı bilgiye dönüşebilmesindeki en büyük etken kuşkusuz kartografik iletişimin başarısıdır. Kartografik iletişimin başarısızlığı ise harita ile bilgi iletimini 
olumsuz yönde etkiler ve bilgi kartografik iletişim sonucunda yararlı bilgiye dönüşmeyebilir, hatta yanlış bilgi aktarımı gerçekleşebilir (Robinson vd., 1995; Uçar ve Uluğtekin, 2006) Örneğin harita kullanıcısının haritayı okumak için yeterli eğitim seviyesinde olmaması, haritada gösterilmiş bilgilerden daha azını almasına neden olabilir. Öte yandan harita üzerine bilgi aktaran kişiler bu konuda uzman olmayabilir. Ayrıca haritada işlenecek çevresel konu ile ilgili bilgiler, yöntemlerin yetersizliği nedeniyle istenilen doğrulukta toplanmamış ya da güncel durumu yansıtmıyor olabilir. Kartografik iletişimdeki olumsuzlukların giderilmesi haritanın kullanımını kolaylaştıracak, kullanıcıda harita kullanma bilincini oluşturacak ve harita üreticilerini daha nitelikli haritaların üretilmesi için araştırmalar yapmaya teşvik edecektir.

Yapılan birçok çalışmada, öğrencilere yaşadıkları mekânı ve evreni daha iyi anlama imkânı veren harita becerilerinin faydalarından söz edilmiştir. Bu çalışmalarla ilk ve ortaöğretimde coğrafya eğitiminin ayrılmaz bir parçası olan haritaların olabildiğince kullanılması öğrenim ve öğretim sürecine ve bu sürecin sonucunda öğrencilerde meydana gelmesi beklenen olumlu yöndeki davranış değişikliğine katkı sağlayacağı ortaya konmuştur. (Uluğtekin, 1989; Doğanay, 1993; Ünlü vd., 2002; Taş, 2006; Yıldız, 2006; Demiralp, 2007; Kızılçaoğlu, 2007; Ertuğrul, 2008; Koç, 2008; Duman ve Girgin, 2007; Üzümcü, 2007; İncekara ve Kantürk, 2010). Ayrıca öğrencilerin alan, yön, mesafe, ölçek gibi konularla ilgili problem çözme yeteneklerinin geliştirilmesi ve yaşanılan dünyanın ve içinde bulunulan ortamın doğal, beşeri ve ekonomik özelliklerinin daha iyi anlaşılması derslerde haritaların etkin bir şekilde kullanımı ile yakından ilişkilidir (McClure, 1992; Girgin vd., 2002; Öztürk, 2006; Taş, 2006; Duman ve Girgin, 2007; Üzümcü, 2007; İncekara ve Kantürk, 2010).

Harita kullanımının gerekliliğinin, yukarıda adı geçen kaynaklarda ve daha birçok kaynakta ve özellikle de MEB tarafından önemle vurgulanması, haritaların öğretim alanında etkin olarak kullanılabildiği anlamına gelmemektedir. Yine yapılan araştırmalarda harita kullanma becerisinin eğitim alanı içinde yeterince kazanılamadığı ve gerek eğitim alanında gerekse günlük hayatta harita kullanımı konusunda gelişmiş ülkelerin gerisinde kalındığı belirtilmiştir (Yıldız, 2006; Üzümcü, 2007; Ertuğrul, 2008; Koç, 2008; Buğdaycı ve Bildirici, 2009; İncekara ve Kantürk, 2010, Buğdayc1, 2012).

Daha önce sosyal bilgiler ve coğrafya alanında eğitimde harita kullanımı ile ilgili yapılan araştırmalarla, sosyal bilgiler ve coğrafya alanında harita bilgileri konusunda ciddi bir kaynak ihtiyacının olduğu, müfredatta kartografya açısından harita bilgilerinde eksiklikler, tasarım problemleri, 
atlasların öğrenci seviyesi göz ardı edilerek bilinçsizce kullanıldığı vb. çeşitli nedenlerle harita kullanımının geri planda kaldığı görülmüştür (Buğdayc1, 2012).

Farklı ülkelerde çocuklarda harita kullanımı üzerine yapılan çalışmalar incelendiğinde harita kullanımının ülkemize göre daha erken yaşlarda başladığı görülmektedir. Harita bilgisi ve harita ile ilgili kavramların çok erken yaşlarda öğretilmeye başlanması, özenle hazırlanan harita bilgilerini tanıtan metinlerin hazırlanması harita kullanımına verilen önemi açıkça göstermektedir. Bandrova ve Deleva (1998), çocuklar üzerinde harita okuma ve algılama konularında yaptıkları çalışmalar sonucunda 6-9 yaş grubundaki çocukların haritalara olağanüstü ilgi gösterdiklerini ve haritaları kavrayabildiklerini görmüşlerdir. Çalışmalarının devamında Bulgaristan'da eğitim sistemindeki mevcut haritaların yetersiz olduğunu belirleyip, Bulgaristan Eğitim Bakanlığı'nın da onayıyla eğitim sisteminde kullanılmak üzere çocuklara yönelik belirli yaş gruplarına göre yeni bir atlas takımı üretmişlerdir. Farklı yaş gruplarının (6-7, 8-9, 11-12 vb.) algılama seviyelerine ve okul müfredatına uygun olarak üretilen bu atlaslar, kartograflar, öğretmenler, öğrenciler ve sosyal bilgiler alanında uzman kişilerin bir araya gelerek oluşturdukları ekip çalışmasının ürünleridir (Bandrova ve Dinev, 2005). Şili'de yapılan bir çalışmada ise ilk ve orta öğretimde harita kullanımı 1-2 sınıf, 3-4. sınıf, 5-6 sınıf şeklinde ikili gruplara ayrılmıştır. Eğitim müfredatına bağlı olarak her bir grubun bulunduğu yaşta harita ile neler yapabileceği belirlenmiş ve yaşlarına uygun etkinlikler hazırlanmış ve haritalar üretilmiştir (Palacios, 2009). Eğitim döneminde harita ve harita bilgilerinin Macaristan'da 2. sınıf (7 yaş), Portekiz'de 2. sinıf (7 yaş) (Reyes, 2002), Bulgaristan'da 1. sınıf (7 yaş) (Bandrova ve Dinev, 2005), Endonezya'da 3. sinıftan (9 yaş) (Windiastuti ve diğerleri, 2009) itibaren neredeyse okul dönemlerinin ilk başlangıcında müfredatta yer aldığı görülmektedir. Çocuklarda harita kullanımı ve çocuklar için harita üretimi konusunda çalışmalar yapan ülkelerin başında ise Arjantin, Macaristan (Reyes ve diğerleri, 2005; Erika ve Reyes, 2005; Reyes ve diğerleri, 2008), Portekiz (Reyes, 2002), Brezilya, Çin, Hong Kong, Japonya, Kanada (Quebec), Rusya, Güney Afrika (Anderson, 2003), Bulgaristan (Bandrova ve Dinev, 2005), Avustralya (URL 1), Şili (Palacios, 2009) gelmektedir.

Wiegand (2006) kartografik anlayışın (harita okuma ve anlama) çocukluk dönemi boyunca değişiminin, büyük ölçüde Jean Piaget'nin bilişsel gelişim kuramına göre şekillendiğini belirtmiştir. Bu kuramın özellikle coğrafya eğitimi alanında, çocuk haritaları ve etkileşimleri konularına yön vermede de son derece etkili olduğunu vurgulamıştır. 
Piaget'ye göre harita okuma ve algilama becerisi çocukluk dönemi boyunca niteliksel olarak farklı zihinsel aşamalara göre kademeli olarak gelişir (Wiegand, 2006). Binbaşığlu (1975), Myridis vd., (2007), Üzümcü (2007), Ertuğrul (2008), Piaget'nin bilişsel gelişim kuramını destekleyerek, harita kulanım becerilerinin ögrencilerin gelişim seviyesine göre somuttan soyuta, basitten karmaşığa doğru uygulanması gerektiğini belirtmişlerdir. Ayrıca Ertuğrul (2008), çocukların bilişsel gelişimlerine göre zamanından önce bazı kavramların öğretilmesinin kavram kargaşasına ve yanlış algılamalara neden olacağını ifade etmektedir.

Bilişsel gelişim, çocuğun zihinsel faaliyetlerini içermektedir. MEB tarafından yayınlanmış, mesleki ve teknik okullarda uygulanan öğretim programlarında yer alan yeterlilikleri kazandırmaya yönelik olarak öğrencilere rehberlik etmek amacıyla hazırlanan bireysel öğrenme materyalinde Piaget'nin bilişsel gelişim dönemleri duyu motor dönem $(0-2$ yaş), işlem öncesi dönem (2-7 yaş), somut işlemler dönemi (7-11 yaş) ve soyut işlemler dönemi (11 ve üzeri) olarak ifade edilmiştir (URL 1). Milli Eğitim Bakanlığı'nda eğitim ve öğretim müfredatı çocukların bilişsel gelişimlerine göre planlanmaktadır. MEB'e bağlı Talim Terbiye Kurulu'nun internet sayfasında (URL 2) tüm ilköğretim ve orta öğretim derslerine ait öğretim programları içinde programın temel yaklaşımı, vizyonu, programın becerisi gibi kavramların açıklandığı bir bölüm oluşturulmuştur. Ülkemizde harita kullanımı ilk olarak ilköğretim 4. sınıfta (10 yaş) sosyal bilgiler dersiyle başlar. Sosyal bilgiler (6 ve 7. sınıf) dersine ait öğretim programının becerileri bölümünde, haritaların sosyal bilgiler dersindeki önemi, öğrencilere harita bilgisinin öğretilmesinin gerekliliği ve nasıl öğretilmesi gerektiği gibi konular ele alınmıştır. Ders kitaplarında ve atlaslarda yer alan haritaların da aynı şekilde derecelendirilerek, öğrencilerin algılama seviyeleri dikkate alınarak öğretilmesi gerektiği açık bir şekilde ifade edilmiştir. Öğretim programında "Harita ve Atlas Kullanımı" adıyla oluşturulan bölümde, öğrencilerden kendi seviyelerine uygun harita türlerini okuyabilmeleri, bunun yanında yine kendi seviyelerine uygun haritalar üzerinde çalışabilmeleri beklentisi üzerinde durulmuştur. Harita becerilerinin kazandırılmasında öğrencilerin gelişimsel özelliklerinin dikkate alınması gerektiği ve ilköğretim öğrencileri için bu becerinin basamaklandırılarak verilmesi gerektiğibelirtilmektedir (URL 1).

Metinde yer alan, "Öğrencilerden kendi seviyelerine uygun harita türlerini okuyabilmeleri, bunun yanında yine kendi seviyelerine uygun haritalar üzerinde çalışabilmeleri" beklentisinin karşılanabilmesi için öncelikle öğrencilerin kullandığı haritaların eğitim amaçlı olarak üretilmesi ve çocukların algılama ve eğitim seviyelerine uygun olması gerekir. Bununla 
birlikte haritaların çocuk kullanıcılar tarafından etkin olarak kullanılabilmesi için kartografik tasarım ilkelerine uyularak tasarlanmış olması gerekir.

\section{Kartografik Tasarım}

Büyük ölçekli haritalarda olduğu gibi küçük ölçekli olan tematik haritaların bir yapım yönetmeliği yoktur. Kartograflar, genel kabul görmüş temel kurallar dışında kartografik tasarımda özgürdür. Kartografik tasarımın temel amaçlarından birisi üretilen haritanın kullanıcı tarafından etkin olarak kullanımının sağlanmasıdır.

Kartografik tasarım genelleştirme, işaretleştirme ve üretim olmak üzere üç temel başlık altında incelenmelidir (Robinson vd., 1995). Ders kitaplarında yer alan haritalar kartografik tasarım açısından bu üç temel bileşen kapsamında değerlendirilmelidir. Kartografik tasarım sürecinde genelleştirmenin amacı kullanıcı gereksinmelerini en iyi biçimde karşılayacak düzeyde kaynak haritadaki bilgi fazlasını yok ederek, kullanıcının türetilen haritada sunulan bilgiye kolaylıkla erişebilmesine, dolayısıyla haritanın okunaklılığının artmasına ve estetiğine katkı sağlamaktır (Buğdaycl, 2012). Öğrenme güçlüklerini azaltmak üzere, haritanın amacı ve ölçeği doğrultusunda sunulacak ortama göre (ekran ya da kâğıt) harita üzerinde gösterilecek ya da gösterilmeyecek objelere ve bu objelerin nasıl işaretleştirilmesi gerektiğine karar verme süreci çocuk haritalarının tasarımı açısından da önemli bir aşamadır. Bu nedenle daha çok küçük ölçekli tematik haritaların yer aldığı eğitime yönelik haritaların tasarımında çocuklarda algılama güçlügü yaratacak, harita okumayı zorlaştıracak gereksiz ayrıntılardan kaçınılmalıdır.

Kartografın çevreye ilişkin bilgileri, uygun kartografik işaretlerle harita kullanıcısına aktarması olarak tanımlanan kartografik iletişimi etkileyecek en önemli konulardan birisi de işaretleştirmedir. İşaretleştirme, coğrafi objeler ya da objeye ait bilgilere karşıllk gelen zihinde oluşacak bilgi için en uygun grafik işaretin belirlenmesidir. Coğrafi obje, haritada kartografik obje, yani işaret ile temsil edilir. İşaretler, üzerine coğrafi bilgi kodlanmış grafik gösterimlerdir (Buğdaycı, 2012, Uçar ve Uluğtekin, 2006).

Kartografik işaret sistemi ile bilgi aktarımında nokta, çizgi ve alandan oluşan üç temel grafik elemandan yararlanılır. Grafik elemanlara, grafik ya da görsel değişkenler olarak tanımlanan biçim, büyüklük, yön, beyazlık değeri, renk ve dolgu ile bilgi yüklemesi yapılarak grafik işaretler oluşturulur (Bertin, 1983; Uçar ve Uluğtekin, 2006, Buğdayc1, 2012). Grafik işaretler ikonlar ve semboller olarak sinıflandırılabilir. Ülkemizde tematik haritaların kullanımında harita üzerindeki grafik işaretlerin sıklıkla "sembol" olarak isimlendirildiği görülmektedir. Semboller daha çok sosyo-kültürel 
özelliklerle ilişkili (terazinin adaleti temsil etmesi, beyaz güvercinin barışı temsil etmesi vb.) bazı soyut kavramların gösteriminde kullanılır. Bu nedenle haritada hava alanını gösteren uçak, nehirleri, yolları belirten çizgisel işaretler, ormanları gösteren alansal işaretler somut kavramlar olduğundan sembol olamaz. Bu işaretler ikon olarak adlandırılır. İkonlar ise gösterimi yapılacak olan objenin basit bir grafik resmi ya da önceden beri anlamları bilinen, kullanılagelen işaretlerdir. İkonlar resimsel, geometrik ve alfa nümerik olarak üçe ayrılır.

Harita üzerinde gösterimi yapılan coğrafi verinin nitel ve nicel olmak üzere iki karakteristik özelliğinden söz edilir. Nitel veriler objenin yeri, yapısı, şekli gibi bilgiler içerir. Nicel veriler ise objenin miktarını, değerini ve benzeri büyüklükleri belirten sayısal ifadeleri içerir. Nicel verilerin harita üzerinde gösterimi daha karmaşıktır. Nicel verilerin gösterimi için verilerin sınıflandırılması, sınıf sayısının seçimi, hangi sinfflandırma yönteminin kullanılacağı, hangi harita türünün daha uygun olacağı, haritanın amacı, kullanıcısı, haritanın ölçeği vb. kriterlere göre özenle değerlendirilmelidir. Çocuk haritalarında yapılacak sınıflandırma okuma ve algılama açısından oldukça önemlidir.

Nitel verilerin noktasal, çizgisel ve alansal olarak gösteriminde genellikle görsel değişkenlerden biçim (uçak işaretinin hava alanını temsil etmesi vb.), renk (mavi rengin su objelerini temsil etmesi vb.) ve yön (göç ya da trafik akış yönünün gösterimi vb.) kullanılmaktadır (Şekil 2.1). Nicel verilerin gösteriminde ise büyüklük (işaret boyutlarının verinin büyüklügüüle orantılı olarak değişmesi vb.) ve beyazlık değerinin (yüksek değerler için koyu renkler seçilirken, düşük değerler için beyazlık değerinin artırılması vb.) kullanımı tercih edilir (Şekil 2.2).

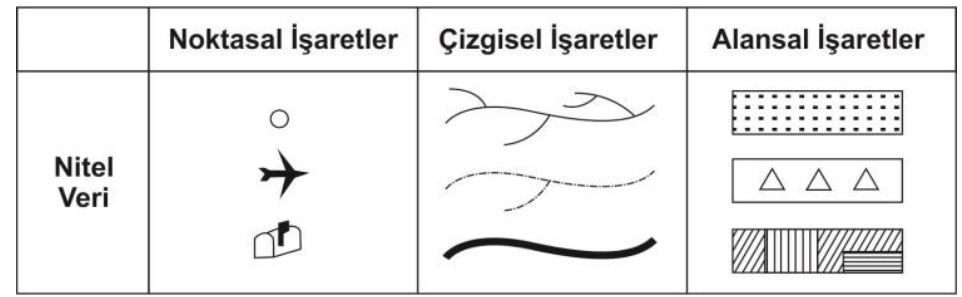

Şekil 2.1 Nitel verilerin nokta, çizgi ve alansal işaretlerle gösterimi (Robinson vd. 1995, Buğdaycı, 2012) 


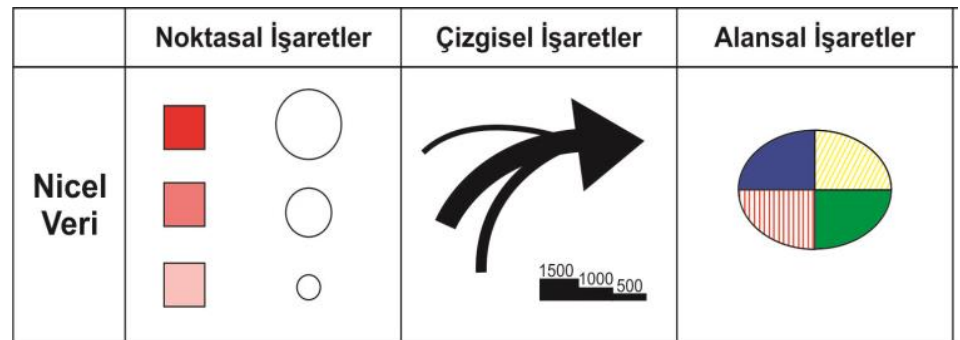

Şekil 2.2 Nicel verilerin nokta, çizgi ve alansal işaretlerle gösterimi (Robinson vd. 1995, Buğdaycı, 2012)

Objelerin özel isimlerinin kartografik işaretlerle gösterilmesi mümkün olmadığından yazı, kartografik işaret sisteminin en önemli parçalarından biridir. Harita ile bilgi aktarımında kullanılan yazılı sözcüklere, grafik değişkenlerin (büyüklük, biçim, yazı türü vb.) uygulanmasıyla farklı anlamlar yüklenir. Bu sözcükler ilgili objenin özel ismi dışında, diğer özellikleri hakkında da bilgi taşır. Yerleşim birimlerinin ismini belirten yazı büyüklüklerinin, bu yerlerin nüfusları hakkında bilgi vermesi ya da mavi renkli yazıların su objelerinin isimlerini göstermesi örnek olarak verilebilir. Uygun tasarlanmış yazı haritanın okunaklılığını artırır. Yazılar noktasal, çizgisel ve alansal objelerin özelliklerine göre uygun şekilde harita üzerine yerleştirilir (Robinson vd., 1995; Slocum vd., 2005).

Nokta işaret haritaları, koroplet haritalar, izoritmik haritalar, oransal işaret haritaları gibi farklı yöntemlerle üretilen tematik haritalar orta öğretim döneminde yoğun olarak kullanılmakla birlikte, öğrencilerin algılamada güçlük çektiği haritaların başında gelmektedir (Buğdaycı, 2012). Bunun nedeni öğrencilere, tematik haritaları nasıl analiz etmeleri ve nasıl okumaları gerektiği konularında gerekli ve yeterli bilginin verilmemesi ve okullarda ders müfredatında tematik haritaların kullanımına dair bilgilerin yer almamasıdır (Dijk vd., 1994; Wiegand, 2005, Buğdaycı, 2012).

Koroplet (renk tonlu) haritalarda belirli bir alansal objeye ait olan istatistiksel veri, alanların renk tonu ve tarama türü ile işaretleştirilir. Renk tonlarının kolaylıkla algılanıp alansal olarak karşılaştırma yapma olanağı vermesi koroplet haritaların sıklıkla kullanılma nedenini açıklar. Tematik haritanın konusu belirlendikten sonra kullanılacak verileri seçerken haritanın amacına uygun olmayan bilgi elemine edilmeli, bilgi belirli yöntemlerle anlamlı şekilde sınıflandırılmalı ve işaretleştirilmelidir. Dağılım karmaşıklığı, renk seçimi, kullanıcının okuma ve algılama yeteneği, sınıf aralığının belirlenmesi, sınıf sayısı, istatistiksel dağılımın hangi yöntem 
kullanılarak en doğru şekilde ifade edileceği gibi konular incelenmelidir (Tyner, 1992; Buğdaycı, 2005; Buğdaycı, 2012).

Veri dağılımlarının yapısı (verilerin hangi değerler etrafında yoğunlaştığını görmek, dağılımın genel yapısı içinde aşırı değerler olup olmadığını ve dağılımın çarpık bir yapıda olup olmadığını anlamak, vb.) hakkında bilgi elde etmek için bu veriler nasıl ve kaç sınıfta sinıflandırılacaktır? Sınıflandırma sürecinde sınıf sayısı, sınıf sınırı, sınıf aralığı ve dağılım aralığının belirlenmesi gerekir (Robinson vd., 1995; Buğdayc1, 2005; Buğdayc1, 2012).

Verilerin çeşitli yöntemlerle belirli özelliklere göre sınıflandırılması çocukların daha kolay algılamalarına yardımcı olur. Özellikle nüfus dağılımı ile ilgili verilerin gösteriminde sıklıkla kullanılan koroplet haritaların iki amacı vardır. Bunlar verinin yoğunluğu, büyüklügünün kartografik gösterimi ve verinin analitik olarak modellenmesidir. Koroplet haritalarda alanlar arasında nüfus değerleri karşılaştırılabilir ve kullanıcının algılaması kolaylaşır (Robinson vd., 1995; Holt vd., 2004; Buğdayc1, 2005; Brewer, 2005; Buğdayc1, 2012).

Sınıf sayısı arttıkça birbirinden kolayca ayırt edilecek renkleri bulmak güçleşeceğinden, uygulamada algılama açısından en uygun olduğu düşüncesiyle genellikle soyut işlemler döneminde (12-13 yaş) 5 sinıf sayısının kullanıldığı görülmektedir (A1'ㄹ, A2, URL 3, Erika ve Reyes, 2005). Daha küçük yaş gruplarında (somut işlemler döneminde) dağılım hakkında ayrıntılı bilgiye gerek duyulmadığından, başka bir deyişle analiz ve yorumlama gerekmeyeceğinden daha az sinıf sayısı (3-4) kullanıldığı görülmektedir (URL 3, A3, A4). Renkler üç farklı yöntem kullanılarak tasarlanması uygundur (Brewer, 1997; Brewer, 2005). Bu yöntemler siralı (sequential), nitel (qualitative) ve ayrım (diverging) yöntemleridir. Sıralı yöntemde renk, en açık renk tonundan en koyu renk tonuna doğru gider. Yüksek değerler koyu düşük değerler ise açık renk tonları ile temsil edilir. Renk tonları arasındaki fark sayısal olarak oransal olmasa da verinin nicel özelliği hakkında bilgi verir (yükseklik bilgisi gösterimi vb.). Nitel yöntemde pastel renkler kullanılmaktadır. Renk tonları arasında nicel bir ilişki yoktur. Ayırt edici olması için renk tonları birbirine zıt renklerde seçilmiştir ve istatistiksel verinin nitel özelliği hakkında bilgi verebilir (bitki örtüsü gösterimi vb.). Ayrım yönteminde ise veri dağılımında kritik bir nokta belirlenerek bu noktadan itibaren renk tonunun farklı bir renk tonuna artan

1 Metin içinde yer alan A1, A2...A4 ifadeleri atlas kaynaklarını belirtmektedir. 
şekilde dönüşmesiyle oluşur. Bu yöntem aynı veri dağılımı içinde pozitif ve negatif değerlerin olduğu dağılım için uygundur (sıcaklık verisi vb.) (Harrower 2003, Buğdayc1, 2012).

Koroplet haritalarda veri dağılımı hakkında kesin bir sonuca varılamaması, bölge içindeki veri değişiminin gizli olması ve sınırlar arasında kesiklik olması koroplet haritaların sakıncalarındandır. Bu sakıncalar bazı yanlış algılamalara neden olabilir. Nokta haritalar ve dasimetrik haritalar, bu yanılgılara çözüm olabilir. Nokta haritalarda bir nokta kesin bir büyüklüğe karşılık gelir. Örneğin nüfus haritasında bir nokta belirli bir sayıda insanı ifade eder ve bu noktalar verinin ait olduğu bölgelerde gösterilir. Koroplet haritalar gibi dasimetrik haritalarda da alansal işaretler kullanılır, ancak kullanılan işaretler, bölge sınırlarından bağımsız olarak verinin yoğunluğuna göre dağılır (Slocum vd., 2005; Buğdayc1, 2012).

Kartografik tasarımın temel bileşenlerinin yanında haritada bulunması gereken temel kavramlara da dikkat edilmesi gerekmektedir. Pafta ağı, işaret tablosu, ölçek, gerekli ise koordinatlar ve projeksiyon bilgileri, veri kaynağı ve tarihi, kullanım ve yararlanma hakkı, harita üreticisinin sorumluluğu gibi konuların da harita tasarımı ve üretimine başlamadan önce dikkatle gözden geçirilmesi gereklidir. Harita üreticileri harita üzerindeki her türlü bilgiden, kartografik tasarımdan sorumludur. Çünkü haritalar kullanıcıyı yanlış yönlendirip hatalı bilgiler almasına neden olabilir. Bu hatalı bilgiler, haritaların izinli ya da izinsiz kopyalanıp basılmasıyla hızlı bir şekilde yayılabilir ve diğer birçok kullanıcının da aynı şekilde hatalı bilgiler almasına neden olabilir. Bu nedenle coğrafi objelere ait verilerin hangi tarihlerde kimler tarafından nasıl elde edildiği, doğru ve güncel olup olmadığı bilinmelidir. Eski tarihli bir veri kullanılacaksa harita kenar bilgisi olarak tarihi yazılmalıdır (Robinson vd., 1995, (Slocum vd., 2005; Buğdaycı, 2012).

Kartografik tasarım bölümünde açıklanan temel kartografik kurallar kapsamında haritaların incelenmesi yapılacaktır.

\section{Sosyal Bilgiler Ders Kitaplarında Yer Alan Haritaların İncelenmesi}

Haritalar bilginin karşılaştırmalı olarak sunulmasında en iyi araçtır. Kullanıcıya aynı bilgiyi farklı yollarla anlatma olanağı vardır. Coğrafi verilerin harita üzerinde gösterilmesi birçok alanda kullanıcıya kolaylık sağlar. Verilerin işaretleştirilerek harita üzerinde sunulması, kullanıcının veriler arasındaki ilişkileri, farklılıkları kolaylıkla algılamasını sağlayacaktır. Haritalar ne kadar iyi hazırlanmışsa, coğrafya o kadar iyi açıklanır. Haritalar 
ne kadar doğru kullanılırsa, coğrafya o kadar iyi anlaşılır. Öğrenciler, haritalardan elde edilen coğrafi bilgileri nasıl analiz edeceğini bilip, anlamalıdır. Örneğin, dünya iklim kuşaklarını gösteren bir haritadaki bilgileri yorumlayabilmeli, dünyadaki genel iklim kuşaklarının oluşumunun nasıl olduğunu sorgulayabilmeli, haritalardan yararlanılarak yaşadığ 1 yerleşim biriminin coğrafi özellikleri hakkında çıkarımlarda bulunabilmeli, belli zaman aralıklarıyla hazırlanan haritalardan yararlanarak bir mekanın coğrafi özelliklerinin değişimini değerlendirebilmeli, bitki topluluklarının dağılışını gösteren haritaları kullanarak, bitki örtüsü ile iklim ve yer şekilleri arasındaki ilişkiyi değerlendirebilmeli, geçmişten günümüze insanların ekonomik faaliyetlerini, geçim tarzlarını haritalardan yararlanarak izah edebilmeli, belli zaman periyotlarına ait Türkiye'de nüfusun dağılışını gösteren noktalama haritalarını inceleyerek, ülkemizde nüfusun tarihsel seyrinin ve yapısal özelliklerinin değişimini sorgulayabilmeli, ülkemizde çeşitli doğal afetlerin dağılışını gösteren haritalardan yararlanarak, bu dağılışta etkili olan etmenleri değerlendirebilmeli, ulaşım haritalarından yararlanarak ulaşım ağı ile yerleşme ve ekonomik faaliyetler arasındaki ilişkiyi değerlendirebilmeli, dünyanın önemli enerji nakil hatlarını gösteren bir harita üzerinde bu hatların bölge ve ülkelere etkilerini değerlendirebilmeli, dünya haritasından yararlanarak bir ülkenin konumunun bölgesel ve küresel etkilerini açılayabilmeli, dünyadaki çatışma alanlarına ilişkin haritaları inceleyerek, bu çatışmaların nedenlerini ve sonuçlarını değerlendirebilmeli, haritalardan yararlanarak doğa kaynaklı riskler konusunda çıkarımlarda bulunabilmelidir.

$\mathrm{Bu}$ bölümde 2005 yılında yapılandırmacı eğitim sisteminden sonra MEB tarafından ders kitabı olarak kabul edilen, 2006-2012 yılları arasında devlet ve özel okullarda okutulan MEB ve farklı özel yayınevlerine ait dört adet sosyal bilgiler ders kitabı incelenmiş, farklı öğretim yıllarında okutulan kitaplarda yer alan haritaların değerlendirilmesi yapılmıştır.

Milli eğitim ders müfredatına bağlı olarak hazırlanan ders kitapları Talim Terbiye Kurulunun onayıyla belirli bir süre (5 yıl) boyunca ders kitabı olarak kabul görmektedir. Ancak sonraki yıllarda müfredat ya da içerikle ilgili düzenlemeler, güncellemeler gerektiğinde kitaplar yenilenebilmektedir. Müfredatta yer alan üniteler, konular ve işleyiş yöntemleri gerek MEB gerekse diğer yayınevlerinin bütün kitaplarında aynıdır. Ders kitaplarının yanında çeşitli atlaslardan ve duvar haritalarından da yararlanıldığı bilinmektedir. Eski programlara göre hazırlanan kitaplarda konu anlatımından sonra değerlendirme sorularıyla üniteler tamamlanırken, yapılandırmacı eğitim programında, coğrafya ve tarih konularına bağlı her öğrenme alanı içinde kazanımlar ve etkinlik örnekleriyle birlikte haritanın 
tüm yönleriyle, gerek sınıf-okul içi gerekse okul dışı etkinliklerle kullanılması istenmiştir (Demiralp, 2007).

6 - 7. siniflarda okutulan sosyal bilgiler ders programinda üniteler, bu ünite sonucunda beklenen kazanımlar, ünite içinde geçen konularla ilişkili etkinlik örnekleri, bu kazanım ve etkinliklere yön veren açıklamalar bölümü yer almaktadır. Bazı ders kitaplarında haritaların kaynakları belirtilmemişken bazılarında Harita Genel Komutanlığı, mevcut durumda böyle bir bakanlık olmamasına rağmen güncellenmeyerek Devlet Meteoroloji ve Turizm Bakanlığ gibi bazı kurumlara ait internet sitelerinden alındığı kitaplarda belirtilmiştir (D1, D2, D3, D4)2. Ad1 verilen sitelerden alınan haritaların kullanıcı gurubu ilköğretim seviyesinde olan öğrenciler değildir. Ayrıca bu siteler eğitim amaçlı değildir, dolayısıyla haritalar da öğrencilerin seviyesine ve öğretim programlarına uygun değildir.

Sosyal bilgiler dersi kapsamında 6-7 sınıflar için kazanım ve etkinlikler içinde harita ve harita kullanımıyla ilişkili olan konular ve ders kitabında yer alan haritalar kartografik tasarım ve özellikle çocuk haritalarının tasarımı açısından incelenerek, mevcut haritaların bu beklenen kazanımlar için ne derece faydalı olabileceği tartışılacaktır.

\subsection{Sinıf ders kitaplarında yer alan haritaların kartografik tasarım açısından değerlendirilmesi}

6. sınıf programında harita ile ilişkili konular 2, 3. ve 5. ünitelerde yer almaktadır. Çizelge 3.1'de bu ünitelere ait kazanım ve etkinlik örnekleri verilmiştir. Ayrıca programda kazanımların gerçekleştirilmesi için çeşitli önerilerin yer aldığı açıklamalar bölümü oluşturulmuştur.

${ }^{2}$ Metinde yer alan D1, D2...D4 ifadeleri ders kitapları kaynaklarını belirtmektedir. 
Çizelge 3.1. Sosyal Bilgiler 6. sınıf programı (sadece harita ile ilişkili kisimlar) (URL 2)

\begin{tabular}{|c|c|c|}
\hline 2.ÜNITTE & KAZANIMLAR & ETKİNLİK ÖRNEKLERİ \\
\hline 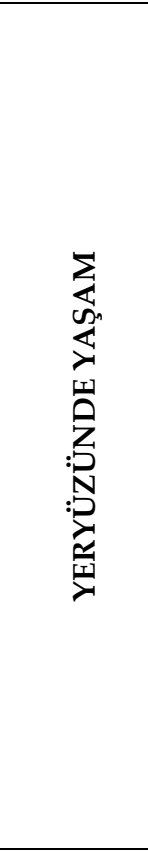 & 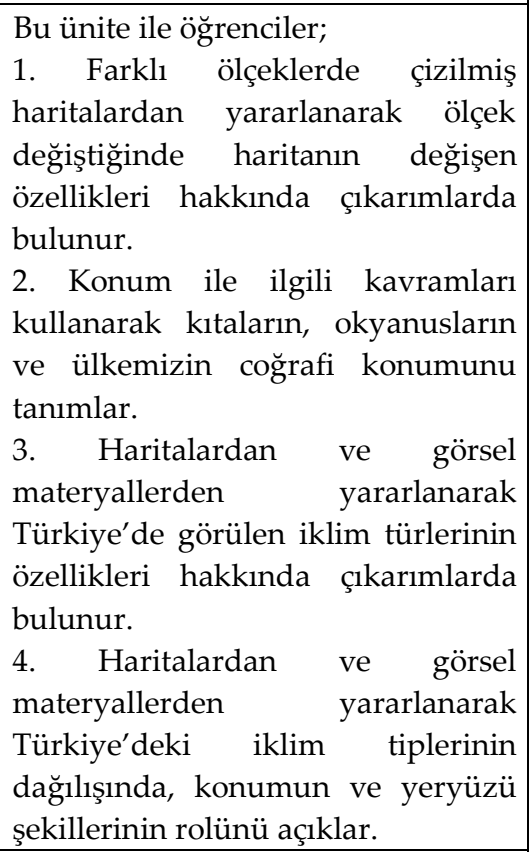 & $\begin{array}{l}\text { "Ülkemizden Yedi Renk" } \\
\text { (Çeşitli harita ve fotoğraflar } \\
\text { incelenerek konum, yeryüzü } \\
\text { şekilleri ve iklim ilişkisi } \\
\text { vurgulanır.) (4) }\end{array}$ \\
\hline 3.ÜNITE & KAZANIMLAR & ETKİNLİK ÖRNEKLERİ \\
\hline 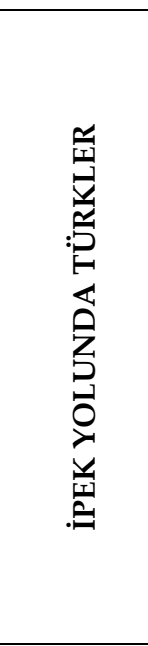 & $\begin{array}{l}\text { Bu ünite ile öğrenciler; } \\
\text { 1. Orta Asya ilk Türk devletlerinin } \\
\text { kültürel özellikleriyle yaşadıkları } \\
\text { yerlerin coğrafî özelliklerini } \\
\text { ilişkilendirir. } \\
\text { 2. İpek Yolu'nun toplumlar arası } \\
\text { siyasal, kültürel ve ekonomik } \\
\text { ilişkilerdeki rolünü fark eder. } \\
\text { 3. Türklerin İslamiyet'i kabulleri ile } \\
\text { birlikte siyasî, sosyal ve kültürel } \\
\text { alanlarda meydana gelen } \\
\text { değişimleri fark eder. }\end{array}$ & $\begin{array}{l}\text { "İpek Yolu ve Türkler" (İpek } \\
\text { Yolu'nun geçtiği bölgelerde } \\
\text { üretilen ürünleri ve bölgelerin } \\
\text { yüzey şekillerini gösteren } \\
\text { haritalar hazırlanarak } \\
\text { toplumlar arasındaki kültürel } \\
\text { ve ekonomik ilişkiler } \\
\text { incelenir.) (1, 2. kazanım) } \\
\text { "İslamiyet ve Türkler" (Eş } \\
\text { zamanlı tarih şeritleri ve } \\
\text { haritalar kullanılarak } \\
\text { İslamiyet'in yayllıs süreci ve } \\
\text { Türklerin İslamiyet'i } \\
\text { benimsemeleri incelenir.) (3. } \\
\text { kazanım) }\end{array}$ \\
\hline 5.ÜNITE & KAZANIMLAR & ETKİNLİK ÖRNEKLERİ \\
\hline
\end{tabular}




\begin{tabular}{|c|c|c|}
\hline 艺 & $\begin{array}{l}\text { Bu ünite ile öğrenciler; } \\
\text { 1. Görsel materyalleri ve verileri } \\
\text { kullanarak dünyada nüfus ve } \\
\text { ekonomik faaliyetlerin dağılışının } \\
\text { nedenleri hakkında çıkarımlarda } \\
\text { bulunur. } \\
\text { 2. Ülkemizin diğer ülkelerle olan } \\
\text { ekonomik ilişkilerini, kaynaklar ve } \\
\text { ihtiyaçlar açısından değerlendirir. }\end{array}$ & $\begin{array}{l}\text { “Dünyamızı Tanıyoruz” } \\
\text { (Dünya haritası üzerine } \\
\text { dünyadaki nüfus ve ekonomik } \\
\text { faaliyetlerle ilgili araştırma } \\
\text { verileri yerleştirilerek dağılışı } \\
\text { etkileyen faktörler belirlenir.) } \\
\text { (1.kazanım) }\end{array}$ \\
\hline
\end{tabular}

Ders kitabında harita ile ilişkili olarak, ilk önce ölçek konusunun yer aldığı görülmektedir. Harita ölçeği, çocuklar için aynı alanın farklı ölçeklerde haritalarını incelediklerinde, karmaşık bir kavram olabilir. Bu kavram, farklı haritalarda daha büyük ya da daha küçük ölçeklerle gösterilen alanların gerçekte büyüklüklerinin değişmediğinin kavranması becerisini gerektirmektedir (Mcclure, 1992; Koç, 2008). Bu beceriyi kazanabilmek için Mcclure (1992), Myridis vd. (2007), Koç (2008) bilinmeyen alanlara geçilmeden önce çocukların yakın çevrelerinden başlayarak ölçek kavramının öğretimine geçilmesini önermektedirler.

Kitapta "Haritalarda ölçek paydası küçüldükçe, başka bir ifade ile ölçek büyüdükçe haritanın gösterdiği ayrıntı artmaktadır" şeklinde "bilgi notu" adı altında bir not bulunmaktadır (D2). Büyük ölçekli ise ayrıntısı fazla, paydası küçük gibi kurallar şeklinde konunun anlatılması farklı amaçlar için üretilmiş farklı ölçeklerde haritalarla karşılaşıldığında karmaşıklığa ve algılama hatalarına neden olabilir. Bugdayci (2012)'de 6 . sınıf öğrencileriyle ölçek kavramı ile ilgili yapılan araştırmanın sonucunda sözü geçen ifadelerin çocukların zihinlerini karıştırdığı aynı mantıkla sorulmuş bazı sorulara doğru cevap verirken bazılarına yanlış cevap verildiği görülmüştür. Harita üzerindeki ayrıntılar haritanın amacına bağlı olarak değişir. Ölçek bu ayrıntıları sınırlayan faktördür. Çünkü her ölçekte her türlü objenin gösterimi yapılamaz. Ölçek küçüldükçe, genelleştirmenin etkisi daha çok hissedilir. Genelleştirme sonucunda harita üzerindeki işaretler, çizgisel objeler, yazılar haritanın amacına göre üzerinden bilgi alınabilecek şekilde basitleştirilir. Bunun sonucunda küçük ölçekli haritalar daha az bilgi içerir. Kazanımlarda belirtilen "farklı ölçeklerde çizilmiş haritalardan yararlanarak ölçek değiştiğinde haritanın değişen özellikleri hakkında çıkarımlarda bulunur" ifadesi için ölçeğin küçülmesiyle harita üzerinde gösterilen bazı objelerin artık görülemediği ve ölçek değiştikçe harita üzerindeki uzunlukların değişmeyeceğini kesinlikle belirtmek gerekir. 
Konu içinde üç farklı ölçekte çizilmiş İstanbul'u gösteren haritalar yer almaktadır (Şekil 3.1). Ancak Haliç̧in görüldüğü 1/100.000 ölçekli harita ile 1/3.750.000 ölçeğinde çizilen haritayı ilişkilendirmek çocuklar açısından kolay olmayabilir. Çünkü çok farklı ölçeklerde çizildiği için ilişkilendirme yapmaları güçtür ve Haliç çocuklar tarafından İstanbul Boğazı gibi algılanabilir.

Ayrıca kitapta Şekil 3.2'de gösterilen harita üzerinden ölçü alınarak Ankara ve Yozgat arasındaki mesafe cetvelle gösterilmiştir. 1/ 7500000 ölçeğinde tasarlanmış harita üzerinden Ankara ve Yozgat il merkezleri arası mesafe $3 \mathrm{~cm}$. olarak ölçülmüss ve ölçeğe göre $225 \mathrm{~km}$ hesaplanmıştır. Google Earth'ten yararlanarak ölçüldüğünde ise iki il merkezi arasındaki mesafe yaklaşık $167 \mathrm{~km}$ 'dir. Gözün görme hassasiyetinin $0.2 \mathrm{~mm}$ olduğu düşünülürse, 1 / 7500000 ölçeğinde bir haritada hata payının en fazla 1.5 $\mathrm{km}$ olması gerekir. Burada bir kaba hata söz konusudur. 


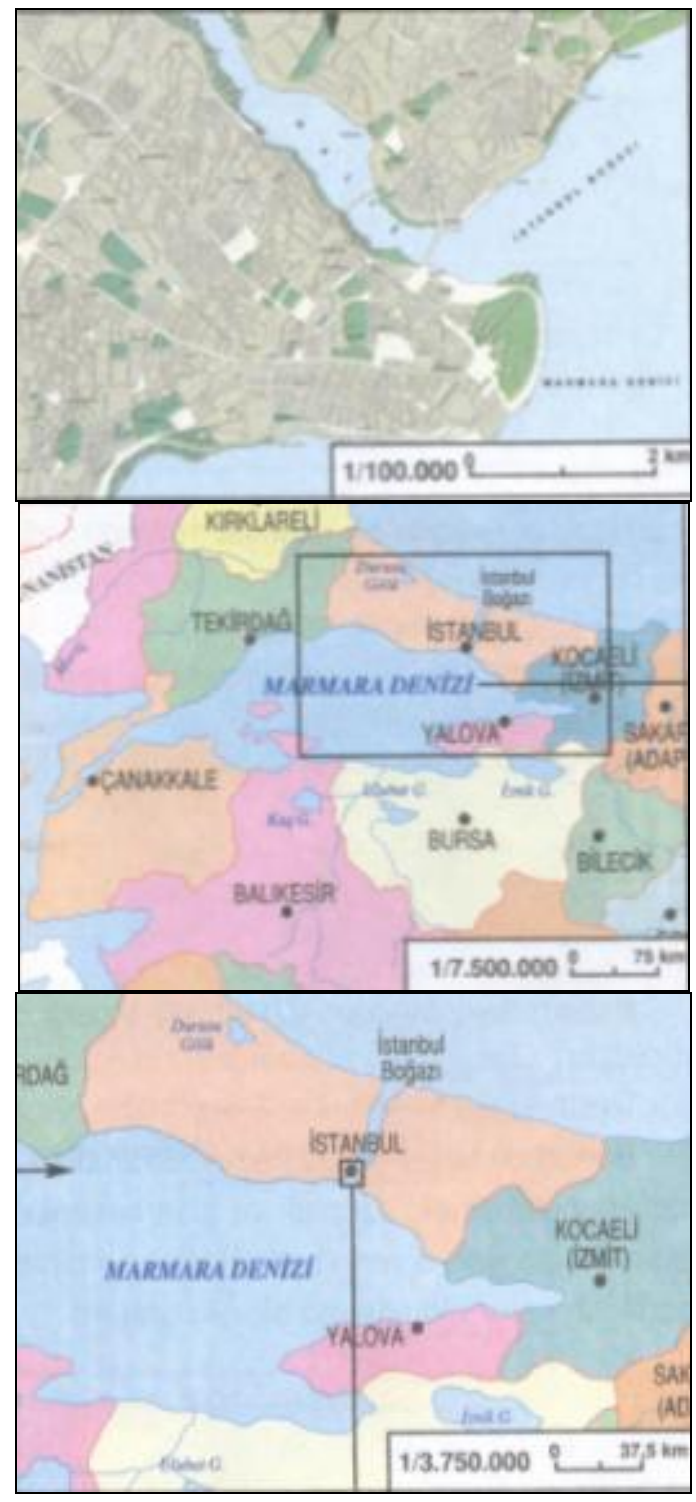

Şekil 3.1 Ölçek konusu için yararlanılan haritalar (D2, küçültülmüş) 


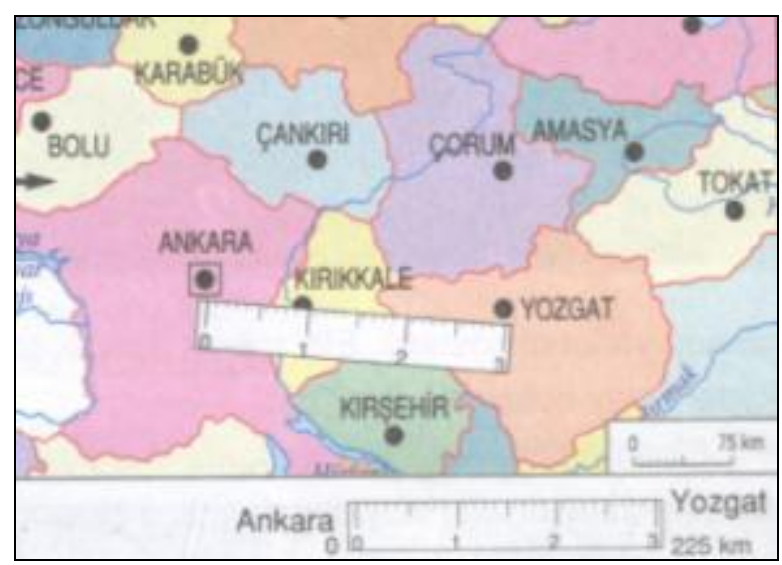

Şekil 3.2 Ölçek hesabının gösterildiği harita örneği (D2, küçültülmüş)

Diğer 6. sınıf kitabında ise üç farklı ölçekte çizilmiş İstanbul haritaları (Şekil 3.3a, Şekil 3.3b) ile ölçek konusu işlenmiştir (D1). İstanbul'un küçük ölçekli haritası üzerinde gösterilen Haliç ve çevresi büyütülerek farklı ölçeklerde gösterilmiştir. Haritalar arasındaki konum ilişkisi anlaşılabilmektedir. Ancak ölçek konusunu ilk kez öğrenecek öğrenciler için A haritasının çok karmaşık olduğu söylenebilir. Öğrencilerin farklı ölçeklerde çizilmiş haritaları karşılaştırabilmeleri için harita üzerindeki objeleri kolaylıkla seçip algılamaları gerekir. Ancak haritaların baskı kalitesi düşük ve okunaklılığı zayıftır.
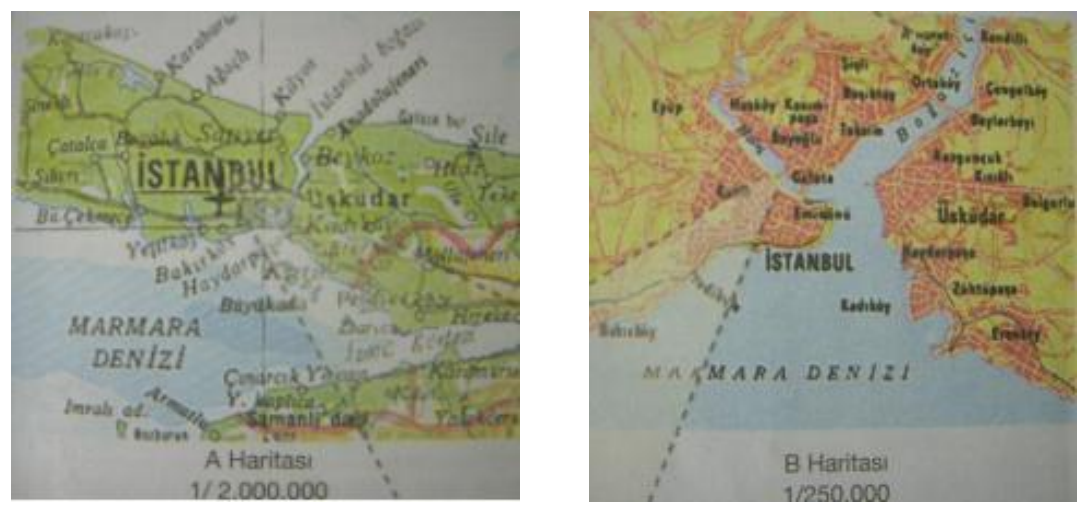

Şekil 3.3a Farklı ölçekte çizilmiş İstanbul A ve B haritaları (D1, küçültülmüş) 


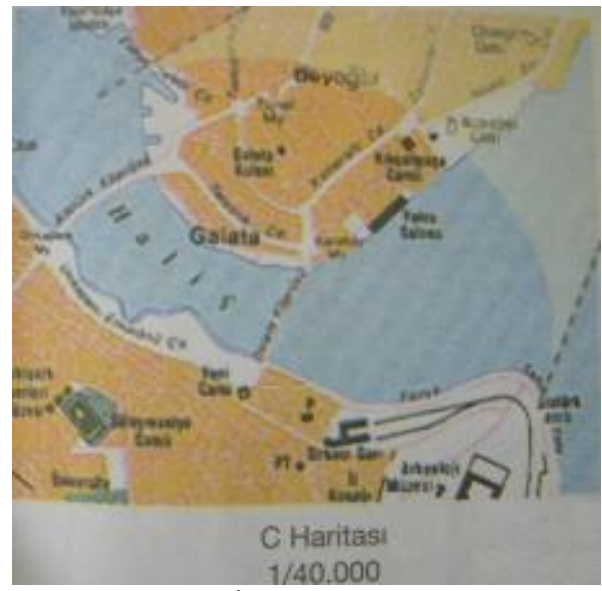

Şekil 3. 3b Farklı ölçekte çizilmiş İstanbul C haritası (D1, küçültülmüş)

Aynı ünite içinde yer alan diğer bir harita ise iklim haritasıdır. Üç farklı iklim türünün gösterildiği haritada sadece Ankara'nın gösterilmesi Ankara'nın iklimiyle ilgili bir bilgi verileceğini akla getirebilir (Şekil 3.4). Ancak konuya ait metin içinde farklı illerin iklimlerinin tartışıldığ 1 görülmüştür. Bu nedenle harita üzerinde önemli il merkezlerinin ikincil bilgi olarak gösterilmesi farklı illerde görülen iklim tiplerinin öğretilmesinde yararlı olabilir.

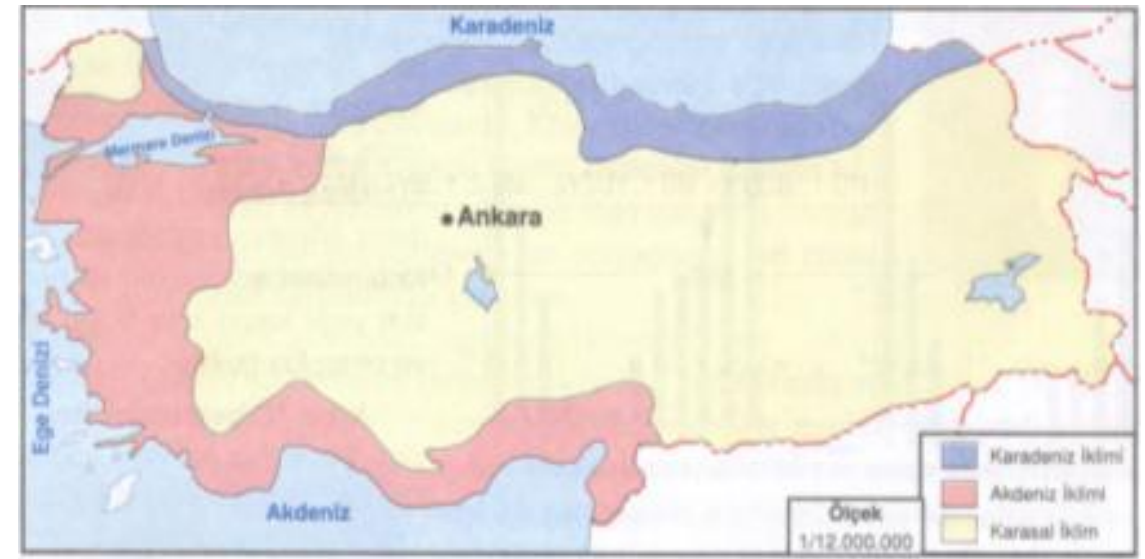

Şekil 3.4 Türkiye' de görülen iklim çeşitleri haritası (D2, küçültülmüş)

İncelenen ilk, orta ya da büyük atlaslarda yer alan iklim haritalarının 12 sınıf seçilerek gösterildiği ve ders kitabındaki haritadan farklı olarak birçok iklim türünün yer aldığ1 dikkat çekmektedir. Şekil 3.5'te gösterilen 
haritanın ilk, orta ve büyük atlaslarda yer aldığı görülmüştür (A5, A6, A7, A8). Bir başka büyük atlasta ise 19 sınıf seçilmiş ve daha farklı iklim türlerinden bahsedilmiştir (A9). Sınıf sayısının fazlalığı ve ders kitabındaki harita ve iklim türlerinin uyuşmaması konunun anlaşılmasını güçleştirebilir. İklim haritalarının ilk orta ve büyük atlaslarda fazla sınıf sayısı kullanılarak tasarlanması, orta öğretim öğrencileri için yorumlama ve analizde kolaylık sağlarken, ilköğretim öğrencilerinin konuyu kavramasını güçleştirecektir. Renk tasarımı açısından değerlendirildiğinde, renklerin dikkatli bakıldığında ayırt edilebilir olduğu ve estetik olarak haritanın güzel göründüğü söylenebilir. Ancak benzer özellikteki objelerin aynı rengin farklı tonlarıyla işaretleştirilmesi algılamayı kolaylaştıracaktır. Başka bir ifade ile Karadeniz iklimine ait iklim türlerinin yeşil rengin farklı tonlarıyla gösterilmesi, diğer iklimlere ait türlerin de aynı rengin farklı tonlarının (Akdeniz iklimi için kırmızının farklı tonları, bozkır iklimi için sarının farklı tonlarının kullanımı gibi) kullanılması ile algılamada kolaylık sağlanabilir. Böylece çok sayıda farklı renk kullanılmamış olur (Brewer, 1997; Brewer, 2005).

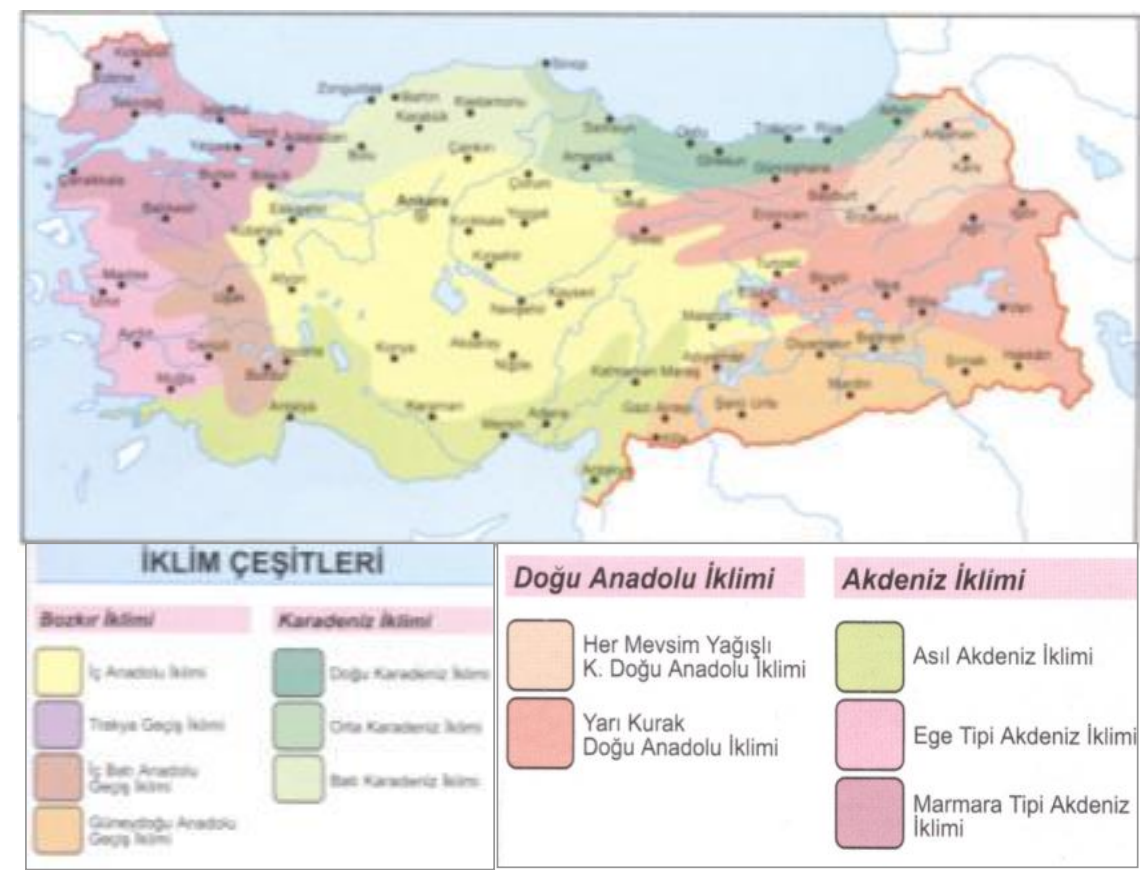

Şekil 3.5. Türkiye'de görülen iklim çeşitleri haritası ve işaret tablosu (A5, küçültülmüş) 
"İpek Yolunda Türkler" ünitesinden itibaren 6. ve 7. sinif sosyal bilgiler derslerinde yoğun olarak tarih haritalarının kullanımı başlar. Tarih haritalarının kartografik tasarımında bazı farklılıkların olduğu görülmektedir. Aynı konuya ait farklı kişilerce tasarlanmış haritalarda farklı coğrafi objelerin gösterilmesi (bazılarında nehirler, göller gösterilirken bazılarında gösterilmemesi gibi), farklı resimsel işaretlerin kullanılması nedeniyle çok sayıda farklı işaretin oluştuğu ve aynı konunun gösterildiği bazı haritalarda sınırların örtüşmediği görülmektedir (A10, A11, D1, D2, D3, D4). Bandrova (2009) aynı şekilde tarih haritalarında bütünlük sağlamanın gerektiğini, farklı kişilerce üretilmiş haritalarda birbirinden farklı çok sayıda resimsel işaretlerin kullanıldığı, coğrafi objelerin gösteriminde birliktelik olmadığını belirtmiştir. Bulgaristan tarih atlasları, kartografik tasarımda ve tarih konusunda uzman kişilerin tecrübe ve deneyimleri, öğretmen ve öğrencilerin önerileri alınarak hazırlanmıştır. Bu haritalarda sadece çok önemli coğrafi objelerin gösterildiği (en büyük göller, en uzun nehirler, sınırlar, il merkezleri ya da başkentler), çok sayıda dağ ismi yerine sadece gölgelendirmenin kullanıldığı belirtilmektedir. Ayrıca farklı yaş grupları için farklı içerikte hazırlanması ve coğrafi pafta ağının gösterilmesi gerektiğini vurgulamaktadır.

Tarih haritalarında genellikle geçmişte yapılan savaşların ve eski dönemlerde var olan devletlerin konumları ve hükümdarlarının gösteriminin yapıldığ görülmektedir. Bu bilgilerin gösteriminde resimsel işaretlerin sıklıkla kullanıldığı, yalnızca önemli doğal ve yapay objelerin (nehirler, göller, sınır çizgileri vb.) işaretleştirildiği ve coğrafya haritalarına göre daha az objeye yer verildiği görülmektedir. Resimsel işaretler tasarımları ile temsil ettikleri obje ya da olayları doğrudan anımsatan, çok net olarak anlaşılır bir yapıda oldukları için, çoğu zaman haritada açıklamalarına bakılmaksızın kolayca algılanabilirler. Çocuk haritaları tasarlanırken işaretlerin mümkün olduğunca harita üzerinden kolaylıkla algilanabilecek şekilde seçilmesi çocukların işaret tablosunu çözmek zorunda kalmadan daha çabuk algılamalarını sağlayacaktır.

Ders kitabında yer alan haritaların genellikle küçültülerek basıldığı görülmektedir (D2). Bu nedenle haritaların okunaklılığı zayıftır. Ayrıca haritaların baskı kaliteleri birbirinden farklıdır. Bu nedenle bazı haritaların eski kaynaklardan tarama yapılarak alınmış olduğu (Şekil 3.6), baskı kaliteleri daha iyi olan haritaların ise kitap için özel olarak tasarlandığ 3.7) söylenebilir. 


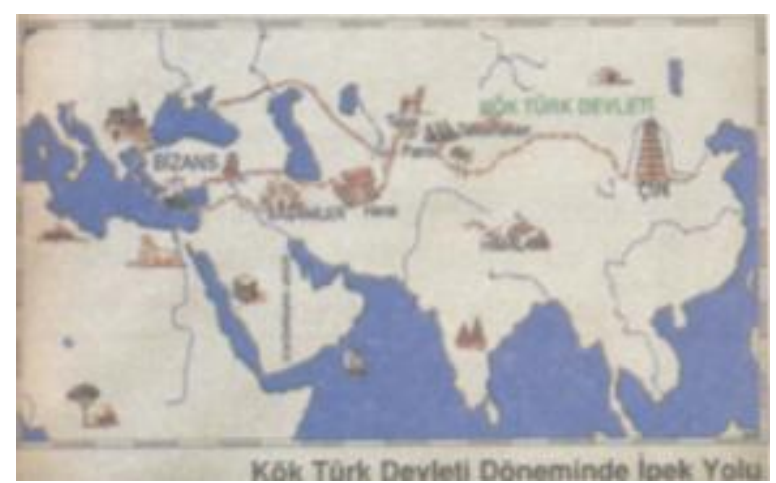

Şekil 3.6 Kök Türk Devleti Döneminde İpek Yolu haritası (D2, küçültülmüş)

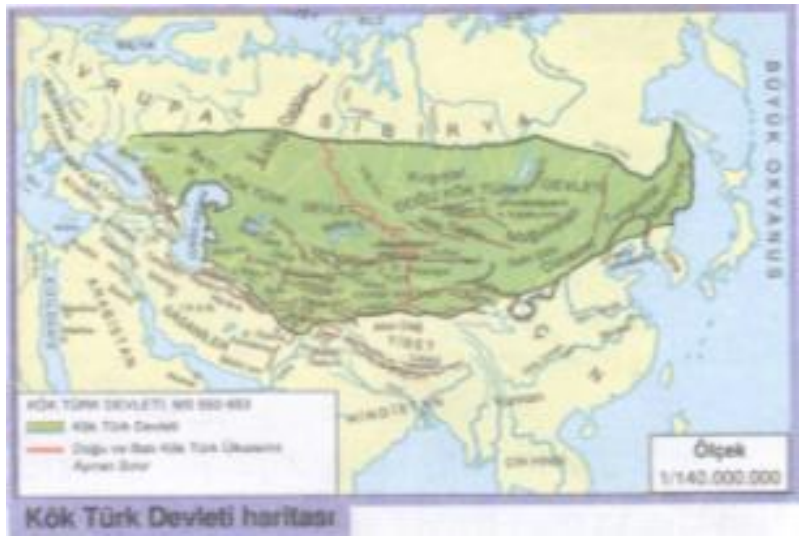

Şekil 3.7 Kök Türk Devleti haritası (D2, küçültülmüş)

\subsection{Sinıf ders kitaplarında yer alan haritaların kartografik tasarım açısından değerlendirilmesi}

7. sınıf programında harita ile ilişkili konular ise 2. ünitede yer almaktadır. Çizelge $3.2^{\prime}$ de bu üniteye ait kazanım ve etkinlik örnekleri verilmiştir.

7. sınıf ders müfredatında daha çok tarih konularının işlendiği ve tarih haritalarına yer verildiği görülmektedir. Tarih haritalarının tümünde coğrafi pafta ağının gösterilmediği, farklı haritalarda farklı coğrafi objelerin yer aldığı ve farklı resimsel işaretlerin kullanıldığı, baskı problemlerinin olduğu ve haritaların çok küçük basıldığı dikkat çekmektedir (Şekil 3.8a, Şekil 3.8b). Tarih haritalarının kaynağı, harita üzerine aktarılan bilginin doğruluğu oldukça önemlidir. Bu nedenle haritaların kaynağı, nereden 
alındığı, kim tarafından tasarlandığı vb. bilgiler harita üzerindeki bilgilerin güvenilirliği açısından belirtilmelidir.

Çizelge 3.2. Sosyal Bilgiler 7. sınıf programı (sadece harita ile ilişkili kisimlar) (URL 2)

\begin{tabular}{|c|c|c|}
\hline 2.ÜNITTE & KAZANIMLAR & ETKİNLİK ÖRNEKLERİ \\
\hline 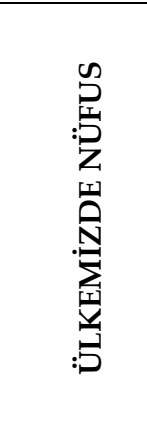 & \begin{tabular}{|l|} 
Bu ünite ile öğrenciler; \\
1. Görsel materyaller ve verilerden \\
yararlanarak Türkiye' de nüfusun \\
dağılışının neden ve sonuçlarını \\
tartısır. \\
2. Tablo ve grafiklerden \\
yararlanarak, ülkemiz nüfusunun \\
özellikleri ile ilgili verileri \\
yorumlar.
\end{tabular} & $\begin{array}{l}\text { 迎 “Nerelerde Yaşıyoruz?” } \\
\text { (Nüfus dağılışın gösteren } \\
\text { haritalar ve fotoğraflar } \\
\text { incelenir.) (1.kazanım) } \\
\text { 迎 “Ülkemizde Bir Gezi” } \\
\text { (Harita ve verilerden } \\
\text { yararlanılarak nüfus } \\
\text { dağılişının neden ve } \\
\text { sonuçları incelenir.) } \\
\text { (1.kazanım) }\end{array}$ \\
\hline
\end{tabular}

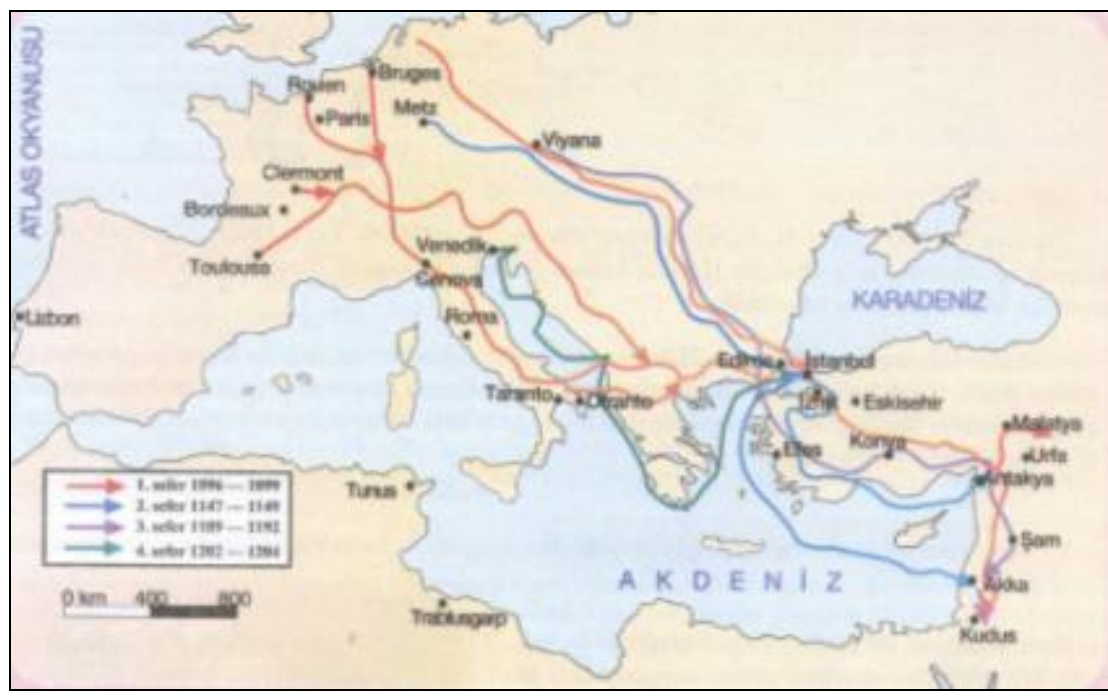

Şekil 3.8a Haçlı Seferleri Haritası (D4, küçültülmüş) 


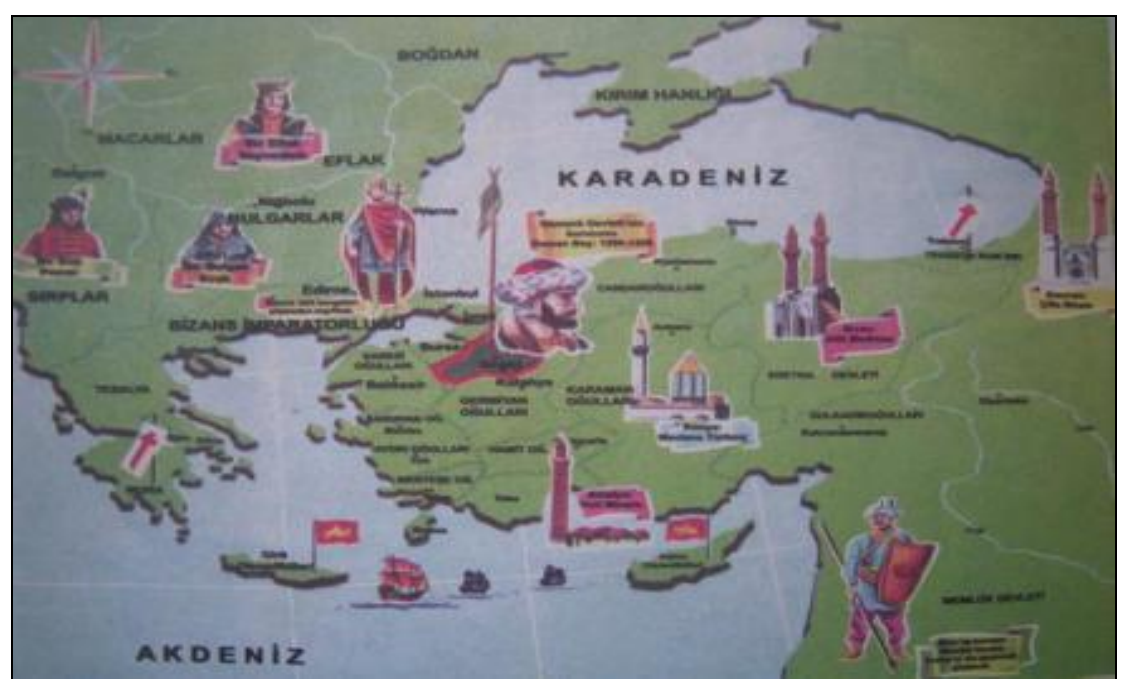

Şekil 3.8b Osmanlı Döneminde Türk Beylikleri Haritası (D3, küçültülmüş)

Ders kitabında öğrencilerden, “Ülkemizde Nüfus” ünitesinde, nüfusun yeryüzü şekilleri ve iklimle ilişkili olarak dağılım gösterdiğini belirtilerek, fiziki harita ile nüfus haritalarını karşılaştırmaları ve nüfusun hangi bölgelerde yoğunlaştığı konusunu tartışmaları istenmektedir (D4). Bu konu için kitapta yer alan haritalar Şekil 3.9a ve Şekil 3.9b'de gösterilmektedir. Fiziki haritanın baskısı oldukça kötü olmakla birlikte, coğrafi objelere ait yazılar da genel kurallara uygun yazılmadığından haritanın okunaklılığı zayıftır. Ayrıca işaret tablosu yoktur. Yeryüzü şekilleri kolaylıkla anlaşılamamaktadır. Nüfus haritasının tasarımında ise dasimetrik yöntem kullanılmıştır. Dasimetrik yöntemde nüfus yoğunluğunun gösteriminde, alansal olarak genelleme yapılmadan birebir yoğunluğun olduğu yerlere göre işaretleştirme yapılması nedeniyle iki harita arasında ilişkilendirme daha kolay yapılabilir. Nüfus yoğunluğu nüfusu az yoğun, orta yoğunlukta ve nüfusun seyrek olduğu yerler olarak üç sınıfla gösterilmiştir. Sınıflara ait renkler arasında hiçbir ilişki yoktur. Bu nedenle veriler arasındaki büyüklük farkı harita üzerinden anlaşılamamaktadır. Çocukların iki farklı haritaya odaklanmaları daha güç olacağından haritaların mümkün olduğu kadar kolay anlaşılır olması, çocukların harita üzerinden bilgi almalarını ve bilgiyi analiz ederek yorumlamalarını kolaylaştıracaktır. Azalan ve artan değerlerin olduğu haritalarda renk seçimi aynı rengin farklı tonlarında yapılması ve yüksek değerler için koyu renklerin, düşük değerler için ise açk renklerin seçilmesi algılamayı kolaylaştıracaktır. 


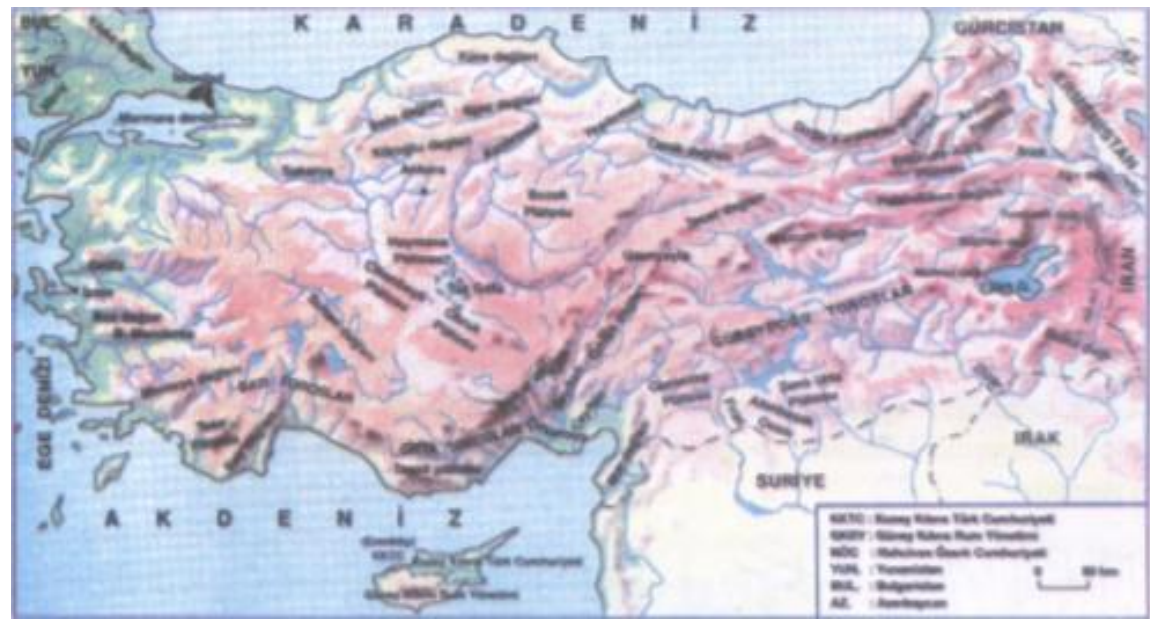

Şekil 3.9a Türkiye Fiziki Haritası (D4, küçültülmüş)

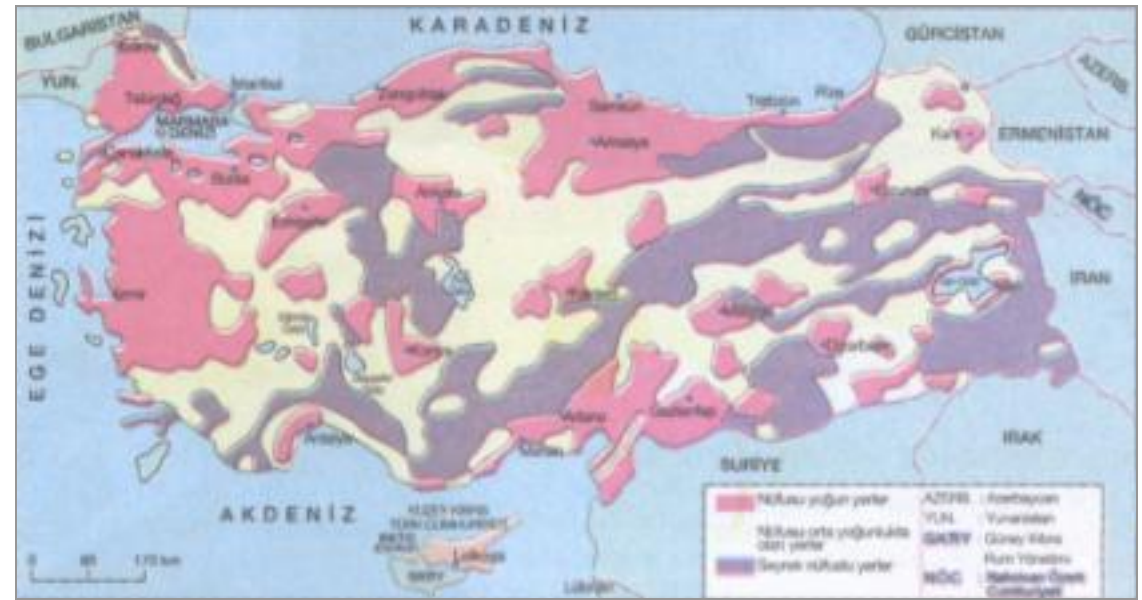

Şekil 3.9b Türkiye Nüfus Yoğunluğu Haritası (D4, küçültülmüş)

Diğer bir nüfus haritasında ise koroplet harita kullanılmıştır (Şekil 3.10). 5 sınıf belirlenerek tasarlanan haritada en yüksek değer koyu kahverengi ile diğer sınıflarda ise kahverenginin açık tonlarıyla sıralı şekilde işaretleştirilmiştir. Harita üzerinden renklerin kolaylıkla algılanabildiği, renklerin veriler arasındaki nicel ilişkiyi yansıttı̆̆ı söylenebilir. Ancak harita genel olarak incelenecek olursa bazı tasarım problemleri olduğu söylenebilir. Trakya bölümü ile komşu ülkeler arasındaki sınır kırmızı kesikli çizgi ile gösterilirken, Doğu Anadolu ve Güneydoğu Anadolu bölgesi ile komşu ülkeler arasındaki ülke sınırı kıyı sınırı gibi gösterilmiştir. 


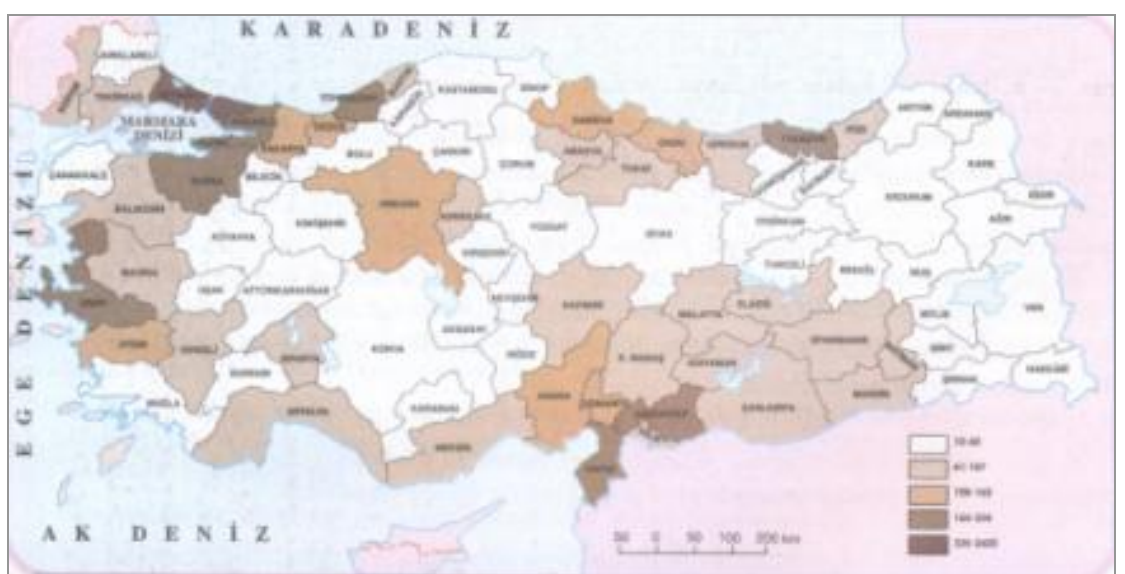

Şekil 3.10 Türkiye Nüfus Yoğunluğu Haritası (D4, küçültülmüş)

7. sinif ders kitabında yer alan koroplet harita olarak tasarlanan diğer bir nüfus haritasında renklerin kolaylıkla algılanamadığı ve resimsel işaretle kişi sayısının belirtildiği görülür (Şekil 3.11). Resimsel işaretin 10 kişiyi gösterdiği belirtilen haritada Bursa'nın nüfusu 200 kişi, Kırşehir'in nüfusu ise 40 kişi olarak algılanmaktadır. Burada da bir kaba hata söz konusudur. Harita, temel kartografya kitaplarında detaylı olarak açıklanan kartografik tasarım açısından değerlendirildiğinde kesinlikle hatalıdır (Robinson vd., 1995; Slocum vd., 2005).
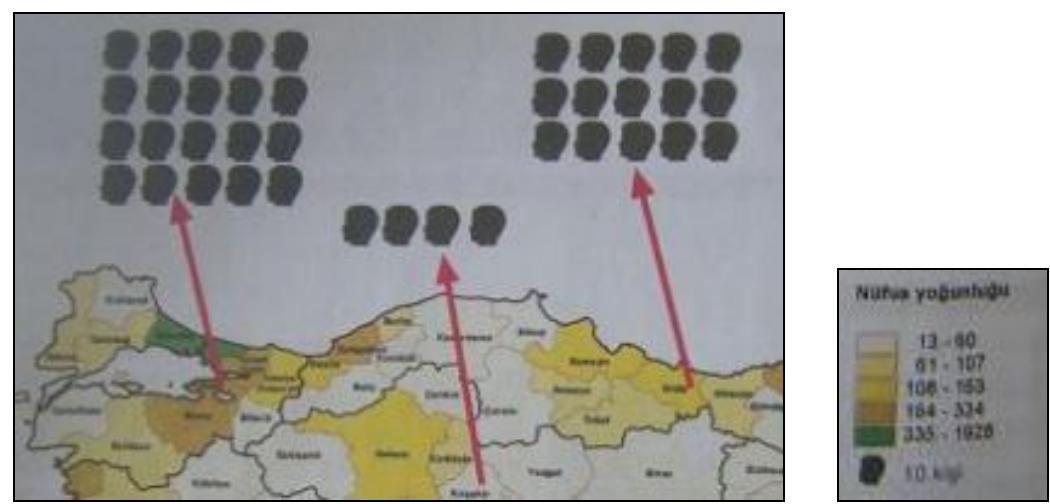

Şekil 3.11 Türkiye Nüfus Yoğunluğu Haritası (D3, küçültülmüş) 
Sosyal Bilimler Dergisi 169

\section{Sonuç ve Öneriler}

Çocuklar için hazırlanan haritaların etkin olarak kullanılabilirliğinin ve yeterliğinin değerlendirilebilmesi için öncelikle çocukların temel düzeyde harita bilgi ve becerisine sahip olmaları gerekir. Bu sayede çocuk kullanıcılar ve harita arasında sağlıklı bir iletişim kurulabilir. Ayrıca öğretmenlerin harita bilgilerinin yeterliliğini ölçmek ve geliştirmek amacıyla çeşitli araştırmalar yapılmalıdır. Sonuç olarak haritaların etkin bir şekilde kullanılabilmesi için öğretmenin harita konusunda yeterli bilgisinin olması, müfredatın bu bilgiyi öğrenciye aktarmasına izin vermesi ve kullanılan haritaların da öğrencinin algılama seviyesine uygun olması, nitelikli olması gerekir. Bu nedenle tüm bu eksiklikler giderilmeden, harita kullanımı için gerekli altyapı oluşturulmadan tasarlanan haritaların, önerilen fikirlerin yararlı olup olamayacağı kesin olarak bilinemez ve test edilemez. Ancak zaman içinde bu problemlerin giderilmesine yönelik çalışmaların ve araştırmaların yapılması sonucu harita kullanımı konusunda ilerleme kaydedilebilir.

Bu çalışmada 6. ve 7. sınıf sosyal bilgiler kitabında yer alan haritaların kısaca temel harita bilgilerinden başlanarak çocuk haritalarının hangi esaslara göre tasarlanması gerektiği belirtilerek, mevcut haritaların eksiklikleri gösterilmiş ve bu konuda çalışacak diğer kişilere yol göstermesi amacıyla bu problemlere ilişkin çözüm önerilerinden bahsedilmiştir. Gerek etkinliklerde gerekse konu anlatımında kullanılan haritaların kartografik tasarımlarının MEB tarafından belirtilen kazanımlar için değerlendirildiğinde yeterli olmadığı görülmektedir. Diğer bütün küçük ölçekli haritaların ya da tematik haritaların kesin tasarım kurallarının olmadığı gibi, çocuk kullanıcılar için tasarlanan haritalara da çizim yönergeleri gibi kesin kurallar konulamaz. Ancak genel tasarım kurallarına dayanarak ilkokul seviyesinde kullanılan (10-13) çocuk haritalarının tasarımları açısından bazı öneriler getirilmesi mümkündür. Bu öneriler harita ile ilişkili tüm konular için, çocuk haritaları ile ilişkili araştırmalar, eğitim amaçlı hazırlanmış nitelikli atlas ve haritaların karşılaştırmalı olarak incelenmesiyle geliştirilmelidir. Ders kitaplarında ve kaynak kitaplarda yer alan harita ve harita ile ilişkili kavramların algılama açısından olumlu ya da olumsuz etkileri değerlendirilmelidir. Eğitim alanında kullanılan haritalar algılama açısından çeşitli yöntemlerle araştırılıp değerlendirilmesi sonucunda algilama hatalarının olmaması sonucu kartografik tasarım zorunluluğunu ortadan kaldırmaz. Haritaların tasarım kuralları vardır ve haritalar kartografik tasarım yöntem ve teknikleriyle tasarlanmak durumundadır. Erken yaşlarda harita kültür ve bilinciyle yetişmiş çocuk 
hayatın her alanında haritaları etkin ve bilinçli olarak kullanabilecektir. Haritalar ve harita tasarımı hep geri planda kaldığından, eğitim alanında haritaların tasarım açısından niteliğine önem verilmediğinden ülkemiz dünya ülkeleri arasında bu kültürün gerisinde kalmıştır.

\section{Kaynakça}

Bandrova, T. \& Deleva A. (1998). Contemporary Cartography for Children in Bulgaria, Joint Seminar on Maps for Special Users, Wroclaw, Polonya.

Bandrova, T., \& Dinev C. (2005). The New Cartographic Products in Bulgaria Modern School Atlases, poster presentation, 22. International Cartographic Conference, CD, A Coruna, Spain.

Bandrova, T. (2009). New Historical Atlases For Educational Needs, 24. International Cartographic Conference, CD, Chile.

Bertin, J. (1983). Semiology of Graphic: Diagrams, Networks, Maps. University of Wisconsin Press, Madison.

Binbaşıŏlu, C. (1975). Gelişim Psikolojsi. Binbaşığlu Yayınevi, Ankara.

Brewer C. A. (1997). Spectral schemes: Controversial Color Use on Maps. Cartography and Geographic Information Science, 24 (4), 203-220.

Brewer, C. A.(2005). Desining beter maps, A guide for GIS users. ESRI, Calfonia.

Buğdaycı, İ. (2012). İlköğretimde Harita Kullanımı Üzerine Bir İnceleme, Doktora tezi, Selçuk Üniversitesi, Fen Bilimleri Enstitüsü, Konya.

Buğdaycı, İ., \& Bildirici, İ.Ö. (2009). Harita Kullanımının Coğrafya Eğitimindeki Önemi, 12. Türkiye Harita Bilimsel ve Teknik Kurultayı, $\mathrm{CD}$, Ankara.

Demiralp N. (2007). Coğrafya Eğitiminde Materyaller ve 2005 Coğrafya Dersi Öğretim Programı. Kastamonu Eğitim Dergisi, 15(1), 373-384

Duman, B., \& Girgin, M. (2007). Eğitim Fakültesi Öğrencilerinin Harita Okuryazarlığına İlişkin Görüşleri. Doğu Coğrafya Dergisi, 12(17), 187202.

Erika G., \& Reyes N. J.J. (2005). How Do Hungarian Pupils and Teachers Use Thematic Maps in Elementary Schools? ICA, Comission on Cartography and Children, joint seminar, CD, Madrid.

Ertuğrul, Z. (2008). İlkögretim 6. Sınıf Öğrencilerinin Harita ve Küre Kullanım Becerilerinin Tespiti. Yüksek lisans tezi, Gazi Üniversitesi, Eğitim Bilimleri Enstitüsü, Ankara.

Girgin, M., Koca, H. \& Sever, R. (2002). Coğrafya Derslerinde Harita Kullanımı ve Başlıca Sorunlar. II. Coğrafya kurultayı, Gazi Üniversitesi, Ankara. 
İncekara, S., \& Kantürk, G. (2010). Sosyal Bilgiler Öğretmen Adaylarının Haritalarla İlgili Temel Görüşleri ve Harita Kullanımına Yönelik Yaklaşımları. Marmara Coğrafya Dergisi, 21, 240-257, İstanbul.

Koç, H. (2008). Coğrafya Öğretim Programındaki Kazanımların Öğrencilerin Harita Beceri Düzeylerine Etkisi. Doktora tezi, Gazi Üniversitesi, Sosyal Bilimler Enstitüsü, Ankara

Mcclure, R.W. (1992). A Conceptual Model for Map Skills Curriculum Develpment Based Upon A Cognitive Field Theory Philosoph (yayınlanmamış doktora tezi). Oklahoma State University, Oklahoma.

MEB (2005). Temel eğitim programı, Sosyal Bilgiler Dersi Harita Folyoları.

Myridis, M., Christodoulou, A., Kalyva, E., Karanikolas, N. \& Lafazani, P. (2007). Cartography and Children: Designing A Multimedia Educational Tool, 23. International Cartographic Conference, Moscow, Russia.

Öztürk, C. (2006). Sosyal Bilgiler: Toplumsal Yaşama Disiplinlerarası Bir Bakış. Hayat Bilgisi ve Sosyal Bilgiler Öğretimi. Pegem Yayıncılık, Ankara.

Reyes, N. J. J. (2002). Teaching Maps in Portuguese and Hungarian Elementary Schools A Study Douša. Cartography and Children Comission and the Cartographia para Escolares Woking group, Diamantina, Brazil.

Reyes, N. J. J., Juliarena, M., Cristina, E., Gallé, E., Garra, A. M., Rey, C. A., Alves C., María V. \& Dibiase, A. S. (2005). Reading Thematic Maps in Argentine and Hungarian Schools. 22. International Cartographic Conference, A Coruna Spain.

Reyes, N. J. J., Juliarena, M., Cristina, E., Gallé, E., Garra, A. M., Rey, C. A., Alves C., María V. \& Dibiase, A. S. (2008). Resuming an international project: Map use in Argentineand Hungarian schools. Second International Conference on Cartography \& GIS, Borovets, Bulgaristan, pp.113-122.

Robinson, A. H., Morrison, J.L. \& Muehrcke, P.C. (1995). Elements of Cartography. John Willey \& Sons, USA

Slocum, A. T., McMaster B. R., Kessler, C. F. \& Howard, H. H. (2005) Thematic Cartogaphy and Geographic Visualization. Pearson Education Ltd., USA

Taş, H. İ. (2006). Coğrafya Eğitiminde Görselleştirmenin Önemi: Mekansal Algılamaya Pedogojik Bir Bakış. Doğu Coğrafya Dergisi, 11 (16), 211-238.

Uçar, D., Uluğtekin, N. (2006). Kartografyaya Giriş Ders Notu, yayınlanmamış. 
Uluğtekin, N. (1989). Günümüzde Kartografya Eğitimi. Harita ve Kadastro Mühendisleri Odası Dergisi, Ankara, 64, 51-57.

Ünlü, M., Üçışık, S. \& Özey, R. (2002). Coğrafya Eğitiminde Haritaların Önemi. Marmara Coğrafya Dergisi, İstanbul, 5, 9-25.

Üzümcü, N. O. (2007). İlkögretim 6. Sinıf Sosyal Bilgiler Dersinde Harita Okuma Becerisinin Aktif Ögrenme Yöntemiyle Kazandırılması. Yüksek lisans tezi, Gazi Üniversitesi Eğitim Bilimleri Enstitüsü, Ankara.

Wiegand, P. (2006). Learning and Teaching With Maps. Taylor \& Francis, London: Routledge.

Yıldız, L. (2006). Illkögretim 7. Sinıf Sosyal Bilgiler Derslerindeki Harita, Grafik ve Şekillerin Kavranma Düzeyi (Aksaray İli Örneği). Yüksek lisans tezi, Gazi Üniversitesi, Ĕ̆itim Bilimleri Enstitüsü, Ankara.

URL1<http://megep.meb.gov.tr/mte_program_modul/modul_pdf/141EO000 4.pdf>, Erişim tarihi 20 Ocak 2012

URL2 <http://ttkb.meb.gov.tr/program.aspx>, Erişim tarihi 20 Ocak 2012

URL3 <http://www.oxfordatlasproject.com/>, Erişim tarihi 20 Ocak 2012

\section{Ders Kitapları}

D1. MEB yayınları, 6. Sinıf Sosyal Bilgiler Ders Kitabı, ISBN: 978-975-11-28317, Ders kitabı olarak kabul edildiği tarih: 28.06.2006.

D2. Altın Kitaplar Yayınevi, 6. Sinıf Sosyal Bilgiler Ders Kitabı, ISBN: 978-97521-1100-4, Ders kitabı olarak kabul edildiği tarih: 28.06.2006.

D3. MEB yayınları, 7. Sinıf Sosyal Bilgiler Ders Kitabı, ISBN: 978-975-11-29475, Ders kitabı olarak kabul edildiği tarih: 19.04.2007.

D4. Anittepe Yayıncilık, 7. Sinıf Sosyal Bilgiler Ders Kitabı, ISBN: 978-9758615-96-4, Ders kitabı olarak kabul edildiği tarih: 20.12.2009.

\section{Atlaslar}

A1. Atlas on Geography, 6th grade, DataMap Europe Ltd, Bulgaristan, 2002.

A2. Atlas for 7th grade, DataMap Europe Ltd, Bulgaristan, 2003.

A3. First Atlas, 1-2nd grade, DataMap Europe Ltd., Bulgaristan, 1999.

A4. First Atlas, 1-2nd grade, DataMap Europe Ltd, Bulgaristan, 2001.

A5. İlköğretim İlk Atlas, Taşkın Yayıncılık, Ankara, Baskı yeri ve tarihi: Tuna Matbaacılık, Harita tasarımı: Adnan Çınar.

A6. İlköğretim Orta Atlas: Evrensel İletişim Yayınları, ISBN: 975-9155-54-4, Ankara, Baskı yeri ve tarihi: -, Hairta tasarımı: Adnan Çınar.

A7. İlköğretim Coğrafya Atlası: Yıldıım Yayınları, Ankara, Baskı yeri ve tarihi: - , Hazırlayan: Adnan Çınar.

A8. Büyük Atlas: Yıldırım Yayınları, ISBN: 975-7992-98-4, Ankara, Baskı yeri ve tarihi: Tuna Matbaacılık, 2008. 
Sosyal Bilimler Dergisi 173

A9. Büyük Atlas: Saygı Yayınları, İstanbul, Baskı yeri ve tarihi: Eflatun Matbaacilık, 2008.

A10.Tarih Atlası: Gönül Yayıncılık, Ankara, Baskı yeri ve tarihi: Sistem Ofset, Hazırlayan: Adnan Çınar.

A11.Tarih Atlası: Tutku Yayıncllık, Konya, Baskı yeri ve tarihi: Feryal Matbaacilik. 
İ. BUĞDAYCI, İ. Ö. BILLDIRİCI, B. TARMAN | 174 